Historic, archived document

Do not assume content reflects current scientific knowledge, policies, or practices. 



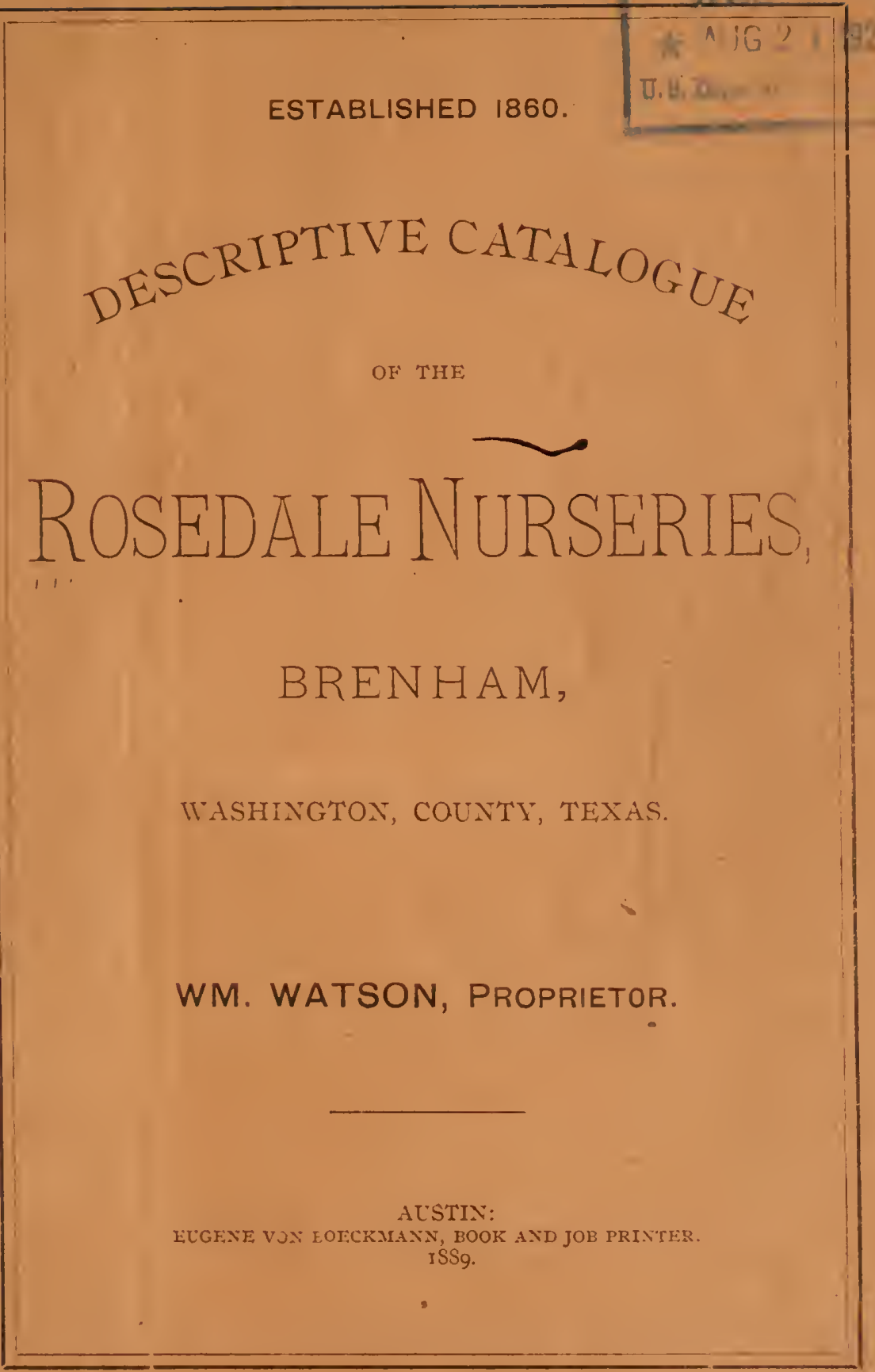




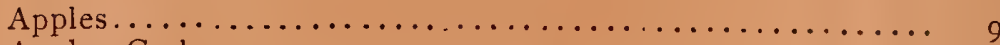

Apples, Crab........................ I 4

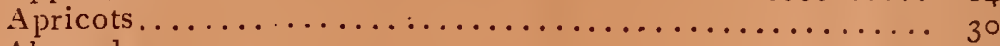

Almonds ................................... 37

Blackberries................................... $44_{40}$

Cherries...................................... 34

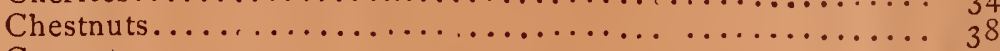

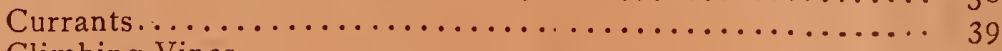

Climbing Vines....................

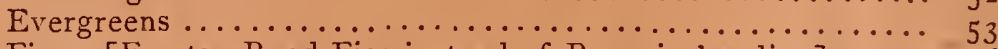

Figs-[Errata: Read Figs instead of Pears in heading]..... $3^{6}$

Grapes................................ 40

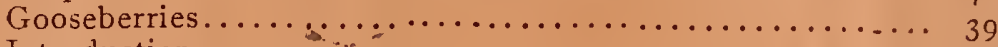

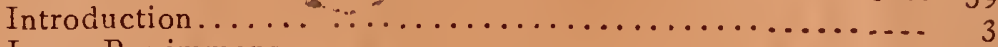

Japan Persimmons........................... 35

Mulberries.............................. 35

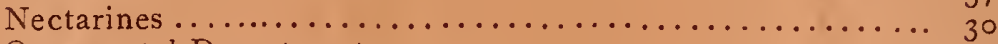

Ornamental Department......................... 45

Ornamental and Shade Trees.................... 45

Ornamental Shrubs.......................... ${ }_{48} 8$

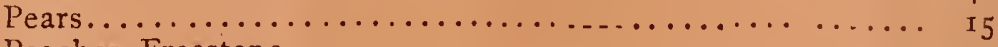

Peaches, Freestone ........................... 19

Peaches, Clingstone......................... 24

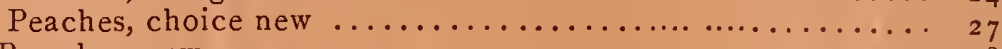

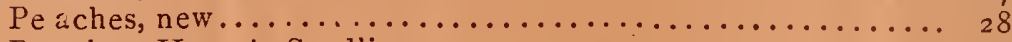

Pe aches, Haupt's Seedlings...................... ${ }_{29}$

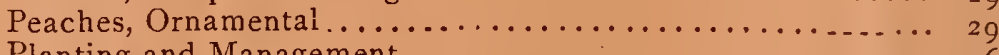

Planting and Management...................... 6

Plums.............................. 3 I

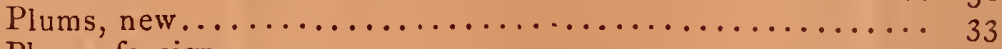

Pluns, foreign $\ldots \ldots \ldots \ldots \ldots \ldots \ldots \ldots \ldots \ldots \ldots \ldots \ldots \ldots, 34$

Pomegranates ............................ 37

Pomegranates, Double Flowering............... $5^{\mathrm{I}}$

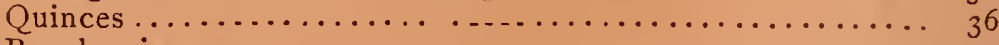

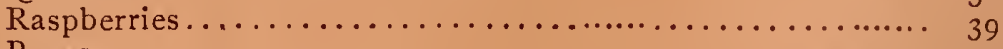

Roses................................ 57

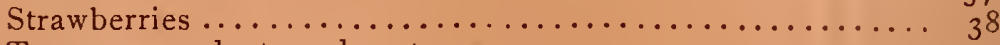

To correspondents and customers $\ldots \ldots \ldots \ldots \ldots \ldots \ldots \ldots,{ }_{4}^{4}$

Terms................................... 5

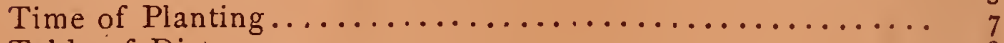

Table of Distances ...................... 8

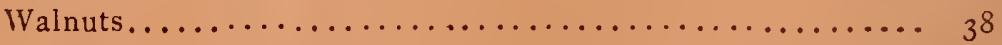

ERRATA -On page 36 , one-third down the page, first heading, instead of "Pears", read "Figs". " 


\title{
ESTABLISHED 1860.
}

DESCRIPTIVE CATALO ${ }_{G}$

\author{
OF THE
}

ROSEDALE NURSERIES,

BRENHAM,

WASHINGTON, COUNTY, TEXAS.

WM. WATSON, PROPRIETOR.

AUSTIN:

EUGENE VON BOECKMANN, BOOK AND JOB PRINTER.

I889. 



\section{INTRODUCTION.}

It is with pleasure that we present our many friends and customers with a new edition of our Descriptive Catalogue, and we beg leave to express our thanks for the liberal patronage extended us in the past, and we hope to continue to merit the confidence of friends and customers.

Since our last edition we have added new sorts to our collection, and have omitted several that our experience have proved no longer worthy of cultivation in our climate.

The Rosedale Nurseries were established in 1860 , and now cover an area of two hundred acres devoted to nursery purposes, and it is with pleasure that we refer to a business career of thirty years and our rapidly increasing sales as evidence of our fair dealings in the past and of the high quality of stock sent out.

The Rosedale Nurseries are situated two miles south-east of Brenham, and on the Western Branch of the Houston \& Texas Central Railroad, and our grounds are open at all times to visitors and customers, who can inspect the stock and see it growing in the nursery.

In presenting this catalogue to the public, we do not claim to offer a general catalogue of trees, plants, etc., of the United States, but simply a catalogue of the trees, plants, etc., that we propagate and have growing here in the Rosedale Nurseries, where all who feel interested can come and see for themselves. We only offer plants that are adapted to Texas, and that have been proven so by experience, except where we offer new kinds that we are testing; in such cases we give the description given us by reliable parties who have had them to fruit or flower.

Our shipping facilities are equal to any in the country, having direct connection from Brenham with all parts of the country by the Houston \& Texas Central and Gulf, Colorado \& Santa Fe Railroads. 
Everything that is possible will be done on our part to place in the hands of customers the articles purchased of us in good condition. Trees and plants are packed with the utmost care in strong bales or boxes, and years of experience renders their safe arrival at long distances as certain as in the immediate neighborhood of the Nursery.

While we are more than anxious that our trees should live and do well, we cannot guarantee them to grow, for the failure to grow is too often due to neglect or improper treatment by the purchaser. There are so many casualties that may befall them in after treatment, of which we can have no oversight or control, that no one could justly ask us to warrant them to live.

ERRORS AND OMISSIONS. - It is our intention to deal justly by all, and while we do everything possible to avoid mistakes in packing, in an extensive business like ours they will sometimes happen in the hurried packing season, and we would request our customers to notify us immediately of any errors that may have been committed, so that we may be allowed to correct them.

AGENTS.-We have agents who travel all over the State, and are supplied with printed blanks, with our names printed on each one, on which to fill out orders, and all orders given them will have our careful attention; but if they should fail to call on you, do not give your order to some dealer, but send it direct to the Nursery, and it will receive our prompt attention. Our express facilities enable us to ship trees promptly and safely to nearly all parts of the State.

The propagation, culture, and growing of nursery stock is under my own supervision and care; customers can feel assured that their wants will receive prompt and careful attention at our hands.

$$
\text { WILLIAM WATSON, }
$$

Rosedale Nurseries, Brenham, Washington county, Texas.

\section{TO CORRESPONDENTS AND CUSTOMERS.}

To avoid mistakes and trouble, we ask our patrons to observe carefully the following rules when writing to, or ordering from us:

In writing, always write in a clear hand, the post office, county 
and State, and sign your name in a legible hand. We get numbers of letters in which parties neglect to even give their post office, and frequently write their name so that it is impossible to make it out. These, of course, we can only throw aside, and the writers probably blame us with negligence when they fail to get a reply.

Our lady correspondents are requested to always sign the same name and to prefix Miss or Mrs.

In ordering by letter write out the order plainly on a separate sheet of paper, or part or page of your letter. Do not combine your order with body of letter, as it may cause mistakes in packing. Specify the size and age of trees desired, and in Pears, whether Standards or Dwarfs; and if the style or variety cannot be supplied, state whether any other will answer; and when this is allowed, state for what purpose the trees are desired. When substitution is allowed, we send equally as good kinds of similar character as to season and quality of fruit.

Persons who are not familiar with the different varieties of fruits and their adaptation to certain localities, or those who contemplate planting new orchards, and only desire assortments of best fruits, can, with confidence, leave their selection to us. In such cases, state the purposes for which the fruit is mainly designed; the season for ripening, in Pears, whether Standards or Dwarfs; in Peaches, whether clingstone or freestone; and in Roses, the color, and whether Mosses, Hybrid, Perpetual, Monthly, or Climbers, are wanted.

We would recommend that orders be send in as early as possible, as late in the season our supply of some particular variety may be exhausted, and Fall planting is considered best.

Give plain and particular directions as to how the packages are to be marked, and by what routes shipped. When no directions are given, we shall use our best judgment in forwarding; but after proper shipment, in all cases, the articles are at the risk of the purchaser, and if delay or loss occurs, the forwarders alone must be held responsible.

\section{TERMS.}

When ordered by letter, orders must be accompanied with cash, unless from old customers, or, orders will be sent C. O. D., unless 
otherwise previously arranged. When ordered through agents, it is strictly cash on delivery of goods at place of delivery.

\section{REMIT'TANCES.}

Remit by postoffice order, or drafts on New York, Galveston or Houston, or by express or registered letter. Postoffice orders, bank drafts, or by express are the best ways to send money.

\section{PRICES.}

We give no prices in our catalogue, as we publish a separate price-list every season, which will be forwarded, on request, to any address. Our prices will be as low as good trees can be grown for.

\section{ON PLANTING AND MANAGEMENT.}

The most desirable soil for fruit trees, is a rich loam. It must not be wet-must be naturally dry or made so by drainage. If soil is very poor, enrich it, by spreading broadcast, well rotted manure, then plow and harrow well before planting. Lay off the rows at required distances and dig holes large enough to contain all the roots in their natural position without crowding or bending them. Use surface soil in filling up, and mix it well among the roots. The roots should not come in contact wiih heating manures, and wood pile manure is especially to be avoided.

\section{AGE OF TREES TO BE PLANTED.}

One year old trees of thrifty growth are the best to plant, excepting pears, cherries and Japan persimmons, which can be two years old. One year old trees can be removed from the nursery with a larger proportion of roots than older trees, and they consequently suffer less in transplanting and make a thriftier, healthier tree. It is much more important to have good roots to a young tree than a large top. Give as many sound roots to a tree, and as little head, as possible. We prefer to cut away every branch, leaving the body one a half to two feet high, and to allow the tree to form its head in its permanent place, rather than in the nursery row.

PREPARATION OF THE TREE.

Before planting, remove all broken roots with a sharp knife. 
One year old peach or apple trees, cut back to a naked stem one and a half to two feet high; leave no side branches. Two years old trees should have their branches cut back to half their length or more, the lower less than those above, cutting in shorter as you go upward, and leave the leader the longest. Plant as deep as the tree was standing in the nursery row, except dwarf pears and cherries, which should be planted sufficiently deep to. cover the stock from two to three inches. Avoid DEEP PLANTING.

In planting the tree, spread the roots out as near in the natural position as possible, mix. the soil well through them, and when the hole is nearly filled up, press the soil down firmly with the feet, finish filling up the hole with loose earth.

\section{TIME OF PLANTING.}

In this climate, vegetation, although inactive in winter for the formation of leaves and new wood, is never so as to new roots. A tree transplanted in November or December will, by the ensuing spring, have formed new roots sufficient to give it a firm hold in the ground, and will grow off rapidly when active vegetation commences. Plant as early after the first killing frost as practicable, and do not delay it until the spring months. Trees can be planted up to the first of March, but success is rendered more certain if the planting be done in the fall.

Grape vines should be cut back to two or three eyes, and only one of these be permitted to grow the first year.

Raspberries and blackberries should be cut back within six inches of the ground.

Trees procured in the fall may be kept safely for planting in the spring by burying them half their length in mellow earth (in a sloping position) where no water is liable to stand; a slight covering of brush or forest leaves over the tops will be of service in case the winter should be severe.

If planting is done late in spring or in dry weather, it is well to give some water when the hole is partially filled; let it settle and fill up with loose earth. No GRASs should be allowed to grow in the young orchard. Neglecting this precaution is the cause of failure in most cases. REMEMBER, YOUNG TREES NEED AS CAREFUL CULTURE AS YOU GIVE YOUR COTTON. 


\section{A TABLE}

SHOWING THE NUMBER OF. TREES OR PLANTS TO THE ACRE.

Distance. No. Trees. Distance. No. Trees. I foot apart, each way...43,560 I2 feet apart, each way...302 2 by 3 feet apart 3 feet apart, each way.... 4,840 I 4 4 5

\begin{tabular}{|c|c|c|}
\hline 66 & "6. & $\begin{array}{l}\ldots 257 \\
\ldots 222\end{array}$ \\
\hline "6 & " & ....193 \\
\hline 16 & $" 6$ & .... I 70 \\
\hline " & 6 & ..... I50 \\
\hline "6 & $" 6$ & .....134 \\
\hline 6 & $s 6$ & .... I 20 \\
\hline 66 & $" 6$ & $\ldots \ldots 108$ \\
\hline "6 & " & $\ldots 6_{9}$ \\
\hline \&6 & "c & $\ldots .48$ \\
\hline
\end{tabular}

RULE-Multiply the distance in feet between the; rows by the distance the plants are apart in the rows, and the product will be the number of square feet for each plant or hill; which divided into the number of feet in an acre $(43,560)$ will give the number of plants or trees to the acre.

DISTANCE FOR PLANTING.

Apples-Standard 20 feet apart each way. Dwarf............... 6 to 8

Pears-Standard............... 25

" Dwarf................. ro to 12

Peach................... I6 to 20 , according to soil. Io to 5 feet apart each way.

Grapes-Concord, Hartford, Clinton

Ives, Herbemont, etc......

" Delaware...............

"Scuppernong, Flowers, and others of same type, 20 to 30 feet in the row, and the rows ro to 20 feet apart, according to quality of soil.

Currants and Gooseberries.........

$\begin{array}{rll}10 & \text { " }\end{array}$

Raspberries and Blackberries.... 3 to 4 by 5 to 7 feet.

Strawberries-for field culture..... I by 3 to $3^{\mathrm{T} / 2}$ feet.

" for garden culture.... I to 2 feet apart. 


\section{Frait Department.}

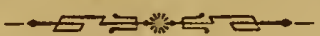

\section{APPLES.}

By proper care and attention we can have first-rate apples in Texas, and in some parts of the State they do as well as in any of the Northern States. In North-eastern, Northern, and most of Western Texas, apples grow as well and fruit as abundantly as peaches do, and they are a much more reliable crop, for where the trees grow and do well we are almost certain to have some apples every year. In this section, and Southern Texas, as a rule, the trees do not live long and the fruit rots badly, though in some favored localities and spots of soil they do very well, and every man on improving a place ought to try a few trees and test the adaptability of his soil to them

To those planting apple trees, we offer the following hints, which, if followed, will make success more certain:

Never plant an apple tree where cotton dies. In planting, dig or plow the ground deeply, and, if any manure be given, spread it broadcast and plow it in; the roots will soon find it out. Cut back the young shoots at planting time half their length, and in future aim at having a broad headed, low branching tree, so as to shade the stem from the sun. Wash the stems of your trees three times a year, in water in which soft soap has been dissolved, and at the same time, say May, July and September, scrape away a little dirt from around the base of the tree, wash that portion clean and cut out any decaying pieces of bark you may see, tracing and killing borers, then put a handful of wood ashes around, and cover up again with the dirt. Do not plant corn or small grain in your orchard, but instead, cotton or peas, but it is best not to plant anything in the orchard. Rabbits often peel the stems of young trees 
in winter, and a good preventive is-tie split corn stalks, a piece of rough cloth or sacking, or even paper, around the stems in December, and remove at the end of February, or merely rub the stem with grease and wash it off in February. We give no prices in this catalogue, as we publish a separate price list every season, which will be sent, on request, to any address.

Red May-A small, flat, red apple, of excellent eating quality. Great bearer. Middle of May to June first.

Early Harvest-Medium size to large; pale yellow; tender; rich subacid, fine flavored. A superb apple. June.

Astrachan Red-Large, yellow, nearly covered with crimson, and fine bloom, juicy, crisp, acid; a beautiful fruit. Tree a thrifty grower; bears young and profusely; the finest of all early apples. May and June.

Carolina Red June-Size medium; dark red; flesh white, tender, subacid. June.

Carolina Watson-Large, conical, greenish, splashed with dull red; flesh crisp and perfumed. Great bearer.

American Summer Pearmain-Medium, oblong; skin smooth, covered with red streaks; tender, juicy, very rich and perfumed. Bears young. June and July.

Sweet Bough-Large, yellow, very sweet. Ripe end of June.

Hominy-(Sops of Wine.)-Medium to large; conical; yellow ground, nearly covered with dark crimson, and a few stripes; flesh white, tender and vinous. Very productive. One of the best apples for Texas. End of June.

Vummer Rose-Small, round, waxen yellow, with red cheek; flesh tender and sprightly. Very fine. June.

Primate-Medium to large, roundish, yellow; flesh tender, juicy, sprightly. One of the finest eating apples. June and July.

Summer Queen-Large, conical, striped and shaded with red; rich and fine flavored. July.

Early Strawberry-Small to medium; yellowish striped and stained with bright red; flesh white, tender, subacid, sprightly. An excellent summer apple. 
Benoni-An excellent apple; tree vigorous, hardy and productive; fruit rather below medium; form roundish, oblate conical; pale yellow, marbled with dark crimson; flesh yellow, jicy, tender. August.

Duchess of Oldenburgh - Of Russian origin. Large size, roundish, streaked with red and yellow; flesh whitish, juicy; flavor sprightly, subacid; tree a vigorous grower, very hardy. July.

Gravenstein-A splended apple, which originated in Germany, and does well in Texas. Fruit large and rather flat; skin yellow, beautifully dashed with light and deep red; flesh firm, tender, crisp and highly flavored. With us, one of the very best.

Summer Russet-Medium, roundish, yellow, covered with light russet; flesh juicy, rich, sweet. Very productive. July and August.

Yellow Bellfiower-Large, oblong, yellow. Great bearer and an excellent fruit.

Sugar Loaf Pippin-Medium, pale yellow, conical. Good quality and productive.

Horse-Large, round, yellow. Bears young and regularly. A good eating apple, and one of the best for cooking and drying.

Red beitigheimer-A rare German variety, very recently intro. duced. Fruit large to very large; skin pale cream color, mostly covered with purplish crimson; flesh white, firm, subacid, with a brisk, pleasant flavor. Tree a free grower and abundant bearer. This is one of the largest and handsomest of apples, and promises to be extensively cultivated. September.

Maiden's Blush-Large, flat, pale yellow, with a red cheek; a good bearer. July and August. One of the very best for Texas.

Fall Pippin-Largest size, roundish oblong; flesh tender and rich. July and August.

Elgin Pippin-(White Spanish ReINeTte) - Large, oblate; bright yellow; subacid, very rich. An excellent and showy fruit. August.

Family-Medium, conical, brown red, with narrow stripes and 
numerous faint specks, giving it a bluish cast; crisp, juicy, and highly flavored; very productive. July and August.

Twenty Ounce-Very large and showy; yellowish, boldly striped and marbled with purplish red. Its large size and handsome appearance render it a great favorite in the market, and in our own nurseries it is one of the finest apples we grow. September.

Mangum-(Carter Gully)-Medium size, oblate; yellowish, red striped; flesh white, firm, juicy and well flavored. August and September. In our nurseries it is an enormous bearer; indeed, it is one of the finest apples on the place.

Rome Bearty-Large; yellow shaded red; flesh tender, rich, jucy. August and September.

Ribston Pippin-Medium, russety yellow, shaded with dull red; flesh deep yellow, firm, crisp, rich. August and September.

$\checkmark$ Carter's Blue-(LAdy FrtzPatRICK)-Very large; green, washed dull brown red, and blue bloom, crisp, sugary and rich; an excellent fruit. August and September.

Equinetelee-Synonyms, Bachelor, King, Iola, Ne Plus Ultra, Byers, Buckinghain, Kentucky, Queen, etc.-Very large, oblate, yellow with bright red cheek and crimson stripes, flesh yellow subacid, very rich and juicy; a magnificent fruit. September. Tree compact and vigorous grower; bears young.

Mamma-Large, oblate, crimson; flesh crisp, juicy and good. A fine Southern fruit. September.

Ben Daris-(New York Pippin, Kentucky Streak, etc).-A large, handsome striped apple of good quality. Tree very hardy, vigorous and productive; a late keeper; one of the very best late apples for Texas. September.

Grimes' Golden-Medium to large, rich golden; flesh yellow, crisp and juicy. October.

Oconee Greening-Large roundish, greenish yellow; flesh yellowish, one grained, crisp and aromatic. October and November.

Buncombe-Synonyms, Meigs, Red Fall Pippin, Jackson Red, Robertson's Pearmain, Red Lady Finger, Red Winter Pearmain- 
A famous North Carolina appie. Large, oblong, greenish yellow, nearly covered with deep carmine, tender, juicy, well flavored. Ripe end of September. Tree upright grower and prolific; an excellent fruit.

White Winter Pearmain-Full medium, obliquely oblong, yellow with bluish cheek sprinkled with small brown dots; flesh yellow, tender, crisp, juicy, pleasant.

Lady Applo-A most beautiful little apple; flat, yellow with a brilliant red cheek; flesh crisp, juicy. Productive. September and keeps late.

Cannon Pearmain--Medium, greenish yellow, shaded red; subacid, very good. A fine bearer and excellent keeping apple. September and October.

Yopp's Favorite-Large, slightly conic; greenish yellow with bluish cheek; flesh white, tender, subacid.

$\checkmark$ Wine Sap-Medium, round, deep red; flesh yellowish, firm, crisp, with a rich, subacid flavor. Keeps well, A first-rate table and cider apple. Tree productive and thrives well on light sandy soils.

Lawver--Large, roundish, dark red, covered with small dots; flesh white, crisp, sprightly. October:

Collasaga-Large, irregular, roundish, yellow, striped with dark red; flesh yellowish, compact, sugary and mild subacid. October and keeps late.

Romanite-Medium, roundish conical, yellow shaded with light red. A fine keeping winter apple.

Nickajack-Large, roundish oblate, yellowish, striped with dull red; flesh firm, moderately tender and juicy. November, and keeps late. Tree vigorous, and open grower, prolific and a very popular Southern apple.

Hall's Red-Small, oblate, shaded with crimson; tender, juicy, rich; quality best. Tree never grows large, is very productive, and one of the finest eating and keeping apples.

Janet-(RAwLES)-Medium to large; yellowish green, stained 
with dull red; roundish conical; flesh white, juicy, subacid. Tree about the last to show its leaves and bloom; almost a sure bearer; productive.

Shockley-Medium; conical, always regular; yellow, with a bright, crimson cheek; flesh firm, sweet or subacid. Tree erect, vigorous and exceedingly productive. Ripens in September, and have been kept in Texas until the next May, thus rendering it one of the most popular and profitable winter apples we grow. The fruit is uniformly of fine size, and the tree bears very young.

Reinette Onze-A very fine winter apple that originated in France.

Zansen Von Welten--An excellent medium sized winter apple of foreign origin.

\section{CRAB APPLES.}

This beautiful fruit succeeds equally well in all sections of the State, thriving and bearing well where many varieties of the apple fail, and are valuable for preserving, jelly, brandying, ornament, and some of the improved sorts are excellent for eating.

Golden Beauty-A most beautiful little yellow apple with a red cheek.

Red Siberian Crab-Good sized of its kind, yellow, suffused all over with bright red. Beautiful.

Transcendant-A large and most beautiful crab, roundish oblong, golden yellow nearly covered with red. Flesh yellow, crisp and subacid. When thorougly ripe they are excellent eating fruit. Bears enormously. July.

Hyslop-An old and very popular variety; fruit large; dark rich red. Flesh yellowish; subacid.

Iady Elgin-Fruit beautiful. Flesh yellowish, moderately juicy, mild subacıd. Tree a vigorous grower and very productive. September.

Van Wyck-Large; skin mottled with bright red, sweet. Tree vigorous. 
Marengo-Fruit large for its class; light yellow shaded with bright red, crisp, juicy. When full ripe it is a mild and pleasant subacid.

Powers' Large-Vigorous, hardy, productive. Fruit, large, beautiful, shaded with crimson. Mild acid.

\section{PEARS.}

It has been emphatically proven by experience that Texas is one of the finest pear countries in the world. By proper culture we are almost certain to have a good crop of fruit every year. The trees grow luxuriantly, bear abundantly and surely, and are longer lived than almost any other kind of fruit tree. Dwarf pears will come into bearing in about two years after planting, and are generally preferred. They grow well, and by planting deep enough to cover the graft, they take root above the graft and run into Standards. The Standards grow well, are longer in coming into bearing, but are longer lived. We have reduced our list to such as have been well tested, and proved valuable for Texas. We can supply additional varieties if desired. These will ripen through the season from last of May to November.

Do not plant pears where cotton dies. Mulch well in the summer. Pears succeed best in rich loams, clayey soils, and sandy soils where the red clay is near the surface.

\section{SELECT LIST.}

Doyenne d'Ete-Small, roundish obovate, russety; yellow, with rosy cheek; fiest white, juicy and sugary. Grows in clusters and ripens to perfection on the tree. The first to ripen in our nurseries. Last of May.

Dearbon's Seeding-Small, turbinate; very regular; skin light yellow; flesh juicy and sweet. Very productive. June.

Osband's Summer-One of the finest early pears. Medium obovate; clear yellow, with red cheek; flesh melting, sweet and perfumed. June and July. 
Brandywine-Large, pyriform, russety, yellowish green; flesh white, juicy, sugary and aromatic. Excellent and productive. July.

Clapp's Favorite-Large, pyriform; yellow, shaded with red; juicy, melting, perfumed. Great bearer, and one of the finest pears for Texas. July.

Bartlett-Large; buttery, rich flavor. A sure and heavy bearer, and one of the best pears for Texas. July and August.

Howell-Large; light waxen yellow; flesh melting, sweet and rich; a vigorous grower and profuse bearer. One of the best pears for Texas.

Tyson-Medium, pyriform, yellow, slightly russeted, with red cheekr flesh juicy, melting, very sugary and perfumed. Tree vigorous, upright and productive. July and August.

Flemish Beauty-Very large; pale yellow, with reddish brown cheek; flesh juicy, melting, sugary and rich; tree vigorous and an enourmous bearer; excellent. One of the best pears for Eastern Texas, and requires to be pulled before ripe and allowed to get mellow in the house. July and August.

Rostiezer-Medium, rather long; dull yellowish green, with reddish brown cheek, flesh juicy, melting, very sugary and aromatic. Trees vigorous. July and August.

Belle Iucrative (Fondanted'Automne)-Large, melting, delicious; fine grower and abundant bearer. July and August.

Des Nonnes--Large, roundish, oblate, greenish with numerous gray dots; flesh juicy, melting and rich. On a little dwarf tree, four years old, in our nursertes, we have picked some three dozen fruits, averaging a half a pound a piece. July and August.

Beurre Giffard-Medium, acute pyriform; greenish yellow, with marbled red cheek; flesh juicy, vinous and perfumed. A fine pear, that should be gathered before ripe and used when ripe. July and August.

Stevens' Gennesee-Very large, roundish, yellow; flesh white, melting, juicy and good. In our nurseries this has proven one of the finest and most productive of pears. 
Seckel-A nost delicious little pear, unsurpassed in flavor. Fruit small, roundish, obovate; skin yellowish brown, with a red cheek; flesh very rich, spicy and sweet. August.

Beurer Superfine-Large, oblate; skin greenish yellow, somewhat russety; flesh, juicy and melting, with a brisk subacid flavor. Tree vigorous and productive. August.

Sheldon-Large, roundish; greenish-russet with a red cheek; flesh melting, rich, juicy and perfumed; first rate. August and September.

Duchesse d'Angouleme--A magnificent pear as a dwarf. Fruit of the largest size (often weighing over a pound) with an irregular, uneven surface; skin greenish yellow, spotted with russet; flesh white, very juicy, with a rich and excellent flavor. Good for eating and cooking. Tree vigorous, productive and perhaps the most valuable pear for Texas. July to September.

Doyenne Gray-Medium, roundish obovate; russety yellowish green; flesh white, fine grained, melting and rich. Very fine. September, and keeps well.

Beurred'Anjou (Ne Plus Meuris)-Fruit large, obtuse pyriform; skin greenish yellow, sprinkled with russet and sometimes with a red cheek; flesh melting, perfumed and excellent. Tree vigorous and productive. August and September.

St. Michael Archangel-Large, rather long; yellow, with sometimes a blush; flesh melting, very juicy and fine. In Texas this ripens very well without rotting. August and September.

Beurre Diel-Very large, obtuse pyriform, yellow marbled with russet, buttery, rich and sugary. Vigorous grower. August. Should be picked before ripe.

Doyenne Boussock-Large, obovate; skin rough; yellow, clouded with russet; flesh very juicy, sweet and aromatic. August and September.

Lawrence-Medium, obtuse pyriform; skin pale yellow; flesh juicy, sweet and good. Tree vigorous, productive, and one of the best orchard trees in Texas. September and October.

Josephine de Malines-Medium, roundish oblate; skin yellowish, 
sprinkled with russet; flesh juicy, sweet and perfumed. A fine. winter keeper.

Louise Bonne de Jersey-Large, oblong pyriform, greenish yel-. low, clouded with dull red; flesh greenish white, juicy, melting and rich. August.

Swan's Orange (ONondaga)-Very large, rich yellow, covered with russet dots; flesh buttery, melting and of good flavor, but variable.

Beurre Easter-Large, roundish obovate; russety yellowish green; llesh fine grained, buttery and melting; very good. Good grower. September till Christmas.

White Doyenne-Full medium obovate; pale yellow, with blush cheek; flesh white, fine grained, buttery, melting and very rich. A well known and highly appreciated pear. September, and keeps well.

Beurre Clairgean-Large, pyriform; yellow shaded with crimson; flesh yellowish', sugary and perfumed. A most beautiful pear that fruits well in our nurseries. August and October.

Vicar of Winkfield-Large, pyriform, juicy. Early winter, pro. lific.

General Todleben-Tree a vigorous grower, irregular, spreading, very productive. Fruit of largest size, obovate, obtuse, pyriform, irregular and uneven surface; dark, greenish yellow; flesh whitish yellow, a little coarse, but when well ripened, juicy, melting, sweet, slightly vinous and aromatic. Sometimes rots badly, otherwise a splendid pear for Texas.

Bieffer-Supposed to be a hybrid between the Bartlett and the Chinese Sand pear. Very vigorous, with healthy, luxuriant foliage, very large, dark green leaves; an early bearer; very productive. Fruit of large size; skin golden yellow with patches and nettings of russet; flesh white and juicy. A splendid pear for preserving, but must be thoroughly ripened before it is good to eat. September.

Le Conte-Supposed to be a hybrid between the old China Sand pear and some of the finer cultivated varieties. Tree an upright 
grower, similar in form to the Lombardy Poplar; a very rapid grower, and when covered with its rich dark green leaves, makes a very ornamental tree; very productive; fruit large, pale lemon yellow, very showy, fine for preserving or cooking. Must be thoroughly ripened before eating; grows well on almost any soils, if not wet, but has not proven in Texas to be entirely free from blight, as is claimed by most parties offering it for sale, though it is probably less subject to this disease than most other pears. July.

The Rural New-Yorker says: "Do not allow a lower price to influence you to purchase of men whose trustworthiness you have reason to doubt. A penny thus saved at the time of purchase will often times be found to be dollars lost years hence."

\section{PEACHES.}

As fine peaches can be grown in Texas as the United States can produce, and as we can have fruit from the first week in May till November, we have a great advantage over the Northern States, particularly for market, as peaches ripen with us nearly two months earlier than in the Northern States. We cannot glut the market with good fruit, but inferior sorts will hardly sell at any price. The finer grafted or budded trees are as hardy, as long-lived and as productive as common seedlings, besides the incomparable superiority of their fruit renders one acre of them worth more, in a marketable sense, than twenty acres of a seedling orchard. This we know from positive experience. Every new peach that we have reason to believe to be good, we get and test in our nurseries. As very early and late peaches are in great demand, we make it a point to have as great a selection of these as can be brought together.

We call special attention to our list of choice new varieties. Price list will be sent to any address when requested.

\section{SELECT LIST-FREESTONE VARIETIES.}

Alezander-Above medium; highly colored in clay soils, less in light soils; flesh greenish white, very juicy, vinous, and of good quality. Like most May peaches with us, it is a partial cling. Ripens about May Ioth to I5th, the time of ripening depending on 
the locality and the season. We have had it to ripen by the 6 th of May. Trees are remarkably prolific, and bear young. It is probably the best and most valuable of all the very early peaches.

Amsden, Brice's Early, Brigg's Red May, Bowers' Early, Cumberland, Downing, Darly Canada, Gov. Garland, Honeywell, Musser, Saunders, Waterloo, Wilder, Etc.-These are new varieties that have been introduced since the Alexander, nearly all of which were claimed to be earlier or larger than the Alexander; but after having been fruited and compared by eminent fruit growers, the conclusion is, that they are all so near alike in size, flavor, color, growth, and season of ripening, as to puzzle the most expert fruit growers to detect the difference between them. We keep a good stock of each variety distinct, so that those who wish to try these sorts, can do so.

Beatrice-Small to medium; deep red. Flesh juicy, vinous, and of good quality. Stands shipping well; an exceedingly prolific bearer. Ripens from the 18 th to $25^{\text {th }}$ of May, immediately after Ałexander.

Early Louise-Larger than Early Beatrice, which it succeeds in immediate maturity; very thin skin and delicate aroma; excellent variety for home consumption only, as it is too tender to carry any distance. Maturity last of May and first of June.

Early Rivers-Large to very large; pale greenish white.: Flesh white, subacid, very vinous and very juicy, of exceedingly delicate skin very thin; maturity end of May and first of June; very prolific; excellent family peach.

Hale's Early-Above medium; greenish white with red cheek; good flavor, very productive, and where it does well, is a very profitable market variety; but in most localities it rots badly. First of June.

Troth's Early-Medium, suffused with red; good quality, very prolific; good for market or family. Middle of June.

Moss' Early-Medium, covered with red, excellent quality; resembles Troth's Early, and ripers about same time.

Early York-L_arge, round, white with red cheek; flesh white, juicy, rich. Early June. Very heavy bearer. 
bergen's Yellow-Largest size, golden yellow, nearly covered with red; flesh yellow and very rich. A splendid peach but a shy bearer. Early June.

Reed's Golden Yellow-Long, lemon-shaped with sharp point, golden yellow color throughout; flesh rich yellow, juicy and fine. The earliest yellow-fleshed peach. Early June.

Amelia-Large to very large, roundish with a point, creamy yellow with beautiful red cheek; flesh white, juicy, melting and rich. Decidedly one of the finest peaches of its season. Early June.

Early Grosse Mignonno-Medium, round, greenish white marbled with red; flesh white grained with red, very juicy and siveet. June.

Eariy Tillotson-Medium, white covered with red, melting, good, very prolific; a favorite market variety. Stands shipping well. Middle of June.

Mountain Rose-Large, creamy with red cheek; flesh white, very juicy and melting. Excellent for family or market; one of the very best June peaches.

Fleitas or Fellow St. John-Large, roundish, orange yellow, with a deep red cheek; juicy, sweet and highly flavored; flesh yellow. Origin, New Orleans; identical with May Beauty of Louisiana. Middle of June, prolific; an excellent peach with us; it ought to have a place in every orchard.

Alice Haupt-Originated in Hays county, Texas, on the farm of W. W. Haupt, Esq., and named in compliment to his daughter. Large, of a beautiful creamy color and white fleshed. Ripenś early in June and quite distinct from any peach of its season. Very prolific; seedling of Chinese cling; sure bearer.

- Stump the World-Very large, creamy white with red cheek; flesh white, juicy and well flavored. A fine market fruit, ripening end of June and first of July.

Old Mizon Free-Large greenish white with red cheek, flesh white, juicy and well flavored. A fine marketing fruit, ripening first of July.

Great Eastern-Very large, round, greenish white with red cheek. Flesh juicy and sweet. This peach was raised in the or- 
chards of P. J. Berckmans, Ga., where the fruits measured fourteen inches in circumference; it has measured fully that in our own nurseries. Middle to last of July; very prolific.

Foster-Resembles the Early Crawford, but ripens a little earlier.

Early Crawford-Very large, oblong, orange yellow with red cheek; flesh yellow, juicy and rich. A splendld peach. July.

Late Crawford-Similar to Early Crawford, but much larger, ten days later, and the finest peach of its season. Last of July.

Susquehanna-Very large, rich yellow with a beautiful red cheek. Flesh juicy, sweet and rich. A magnificient yellow peach, but unfortunately, a shy bearer.

Reeve's Favorite-Very large, roundish oval, yellow with red cheek. Flesh yellow, red at stone, juicy, melting and vinous. A magnificient peach and a good cropper. Last of July.

Elberta-Very large, skin golden yellow; where exposed to the sun, striped with red; flesh yellow, juicy, rich and sweet, fine flavor, supposed to be a seedling of Chinese Cling. Originated in Georgia, where it is considered one of their best peaches for market and family; good shipper.

Thurber-An excellent peach, seedling of Chinese Cling, which it resembles. Large, white, with faintly colored cheek; flesh white, red next seed, very juicy, highly flavored, rather acid; very prolific and sure bearer.

Columbia (Pace, Yellow Indian)-Large, round, dingy yellow, peculiarly marked with dull red. Flesh yellow; melting and rich. Last of July and first of August.

Conkling-Golden yellow, marbled with crimson, large and beautiful; flesh yellow, rich, juicy, good quality. Ripens after Crawford's Early and before Crawford's Late.

Falcon-Originated by Mr. Rivers of England; seedling of the White Nectarine. Fruit large, white, red next seed, red cheek. An excellent peach, with a pleasant, piquant flavor. July ro.

Sea Eagle-Originated by Mr. Rivers. Very large, almost pure white color; white flesh, excellent flavor. Last of July. 
Gaylord-Originated by Dr. M. W. Phillips, of Mississippi. Fruit large, round with sharp point; skin roseate, with red cheek. Flesh white, juicy, rich, superior flavor; small seed. Early August.

Christiana-A beautifnl and most delicious peach; yellow with fine blush, very large; resembles Reeve's Favorite. Ripens be. tween Crawford's Late and Smock. Early August, very fine.

Late Red Rareripe-Large, roundish oval, whitish with marbled red cheek. Flesh white, juicy and rich. Early August.

Walburton Admirable-Large, roundish, greenish white shaded with red. Flesh white, juicy and rich.

Ward's Late-Large, greenish white with red cheek. Flesh juicy and good. July.

Mascogee-A variety of the Columbia with white flesh, size large, skin dingy yellow, nearly covered with crimson, red and dark brown cheek, spotted and somewhat striped like the Columbia. Flesh white with some red veins around the stone, melting, juicy and very good. Maturity beginning of August. Freestone.

Crockett's Late White-Full medium, white with blush cheek. Flesh white to the stone and sweet. Valuable for preserving. Last of August.

Smock-Large, oval, orange yellow, mottled with red and red cheek. Flesh bright yellow, red at stone. A profitable market peach. Last of August.

Princess of Wales-Very large, creamy with red cheek. Flesh melting, rich and excellent. A most beautiful fruit. Last of August.

Libscombe Prize-Originated by the late Dr. Libscombe, of Montgomery, Texas. A magnificent large yellow peach, very juicy; delicious flavor. Last of July and early August.

Newington Free-Very large, whitish, marbled with red and red cheek. Flesh yellowish white, red at the stone. Very fine, and coming in in August, when good market peaches are scarce, it is wery valuable.

Picquet's Late-Large, yellow with red cheek. Flesh yellow, rich. sweet, juicy and highly flavored. Early September. 
Salway-A yellow peach of English origin that bears very heavily in our nurseries. With us it ripens ten days later than Picquet's Late, and is quite as good. September.

Bilyeu's Late Ootober-An accidental seedling, found in Caroline county, Md., by S. G. Bilyeu and introduced by him. Fruit large. Flesh white, with bright red cheek; in size and appearance much like Old Mixon; free; ripening ten days after Smock, one week after late Heath Cling.

Comet-Large, round, orange with a red cheek. Flesh sweet, melting and good. Resembles Bilyeu's.

Prince of Wales-Large, highly colored; flesh rich, melting, excellent flavor; very prolific. August.

Leatherbury's Late-A fine large late peach of yellow flesh. Resembles Smock, and ripens about the same time.

Lord Palmerston-Fruit very large, whitish with a pink cheek; juicy and rich. September. Originated by Mr. Rivers.

Lady Palmerston-Greenish yellow, marbled with crimson. Flesh pale yellow, melting. September. Originated by Mr. Rivers

Baldwin's Late-Medium, roundish oblong; skin greenish white with a pale red cheek. Flesh firm, juicy, melting and well flavored. Ripe October 5 th to 25 th.

Steadley-Originated at Bluffton, Mo.; freestone; ripens later than Heath Cling; white, with faint blush on sunny side; juicy, fine flavor, delicious. First of October.

Jolia--Medium, white with faint red cheek. Flesh white, juicy and good. October till November.

Lady Parham-Medium, yellowish white tinged with red. Flesh white, reddish at the stone, rich and vinous. Raised by the late Thomas Afflect.

Beers' Smock-Fruit large, oval; skin light orange yellow. Flesh yellow, red next seed; rich and juicy. August.

\section{CLINGSTONE VARIETIES.}

Eldred Cling -The finest early cling peach we know of, ripening 
with Hale's Early. The fruit is as large as Crawford's Early, somewhat oval in shape, pale yellow with a beautiful red cheek. Flesh whitish, very juicy and rich. Originated on the farm of $D$. R. Eldred, Washington county, Texas.

Tuskena-Above medium, oblong, skin yellow and deep orange red. Flesh subacid, vinous, good. Last of June. Origin, Mississippi.

General Taylor-Medium, round, skin white, nearly covered with red. Flesh juicy, sweet. Repens July ist. Origin, Missis. sippi.

Flewellen-Large, globular; yellow dowdy, with streaks of red. Flesh yellowish white, red near the stone, very juicy and sweet; ripe July 15 th to $25^{\text {th. }}$.

Congress Cling (Old Mixun Cling)--Large, roundish oval, creamy white with a beautiful blush. Flesh firm, juicy, white, red at stone. An enormous bearer. Early July.

Duff Yellow-Very large, roundish, skin yellow; flesh yellow, firm, juicy; fine flavor. Early July.

Gen. R. E. Lee-A seedling of Chinese Cling; above medium' creamy white with carmine wash. Flesh finely grained, melting, very juicy; fine flavor. Early July.

Stonewall Jackson-Another seedling from Chinese Cling; a fine peach, and first-class in every way. July.

Chinese Cling-Largest size, oval, clear straw color, beautifully marbled with red. Flesh white, extremely juicy, sweet and rich. From roth till end of July.

Lemon Cling-Large oblong, with a protuberance like a lemon; yelloww with red cheek. Flesh yellow, juicy, firm and good. Last of July.

Tippecanoe-Very large, roundish, yellow with red cheek. Flesh yellow, juicy and vinous. August.

Newington Cling-Large, roundish oval, creamy white with red cheek. Flesh firm and juicy. Fine for preserving or brandy. Last of July. 
Blood Cling (RED Indian)-Large, dark claret, very downy. Flesh deep red, and must be thoroughly ripe before eatable. August.

Ringgold Mammoth Cling-Very large, white with a beautiful blush cheek; flesh white, juicy and rich. August.

Heath Cling (White ENGLish)-Large, oval with a sharp apex, creamy white; flesh white to the store, juicy, sweet and good. Popular for preserving. First of September.

Bronough Cling - In every way like Congress Cling, and possesses as good qualities. It ripens in September.

Demming's September Cling-Large, oblong, yellow with red cheek; flesh yellow, red near the stone, firm and juicy. September.

Tinley's October-Medium, white a little washed with red; flesh white and juicy. October.

Eaton's Goiden Cling-Medium, skin golden yellow, faintly marbled with rose; flesh sweet, juicy and rich. August.

Good's October-Large, skin light claret, with red veins; flesh white streaked with red; very juicy, acid and refreshing. Ripe September 25, to October 15 . Of Indian type.

Austin's Late Red-Large, oblong, skin white almost-entirely covered with red. Flesh white, juicy, acid and good. Ripe October I to 15.

Darby-Medium; skin yellowish white, with a slight tinge of red on one side; flesh white to the stone, firm and sweet. Ripe October 15 to 25 .

Van Buren's Golden Dwarf-Large, yellow, with a blush; flesh yellow, juicy and fine, but a light cropper. Here the trees grow some eight feet high and are very ornamental. August.

Peen-To, or Flat Peach of China--A very peculiar shaped peach, being flat like a tomato or biscuit. Medium, white, mottled with red; succeeds well along the coast, but of little value here, as it blooms too early, and seldom sets fruit. 


\section{CHOICE NEW PEACHES.}

Shumacher-Claimed to be the earliest peach known; earlier than Amsden; described as a perfect freestone and exempt from rot, common to the extra early peaches. Fruit large, deep rich red; flesh white, very sweet, juicy and melting; a good keeper; bears transportation well; seed small. Tree very hardy.

Wheatland-Claimed to be the largest, hardiest, best, most productive and handsomest of its season, an improvement on Crawford's Late, and a little earlier. Beautiful golden yellow with crimson cheek. Has not fruited with us.

Roser-Specially recommended for hardiness, late season, and reliability to produce a crop. Fruit large, yellow with a blush on one side, rich, mealy, yet juicy, with a nild subacid flavor. Freestone; ripens in September. Has not fruited with us.

Switzerland-Medium, white flesh, covered with red; juicy, good flavor; very productive. July.

Hance's Golden Rareripe-Large, globular, yellow, nearly covered with dark red; flesh yellow, very juicy, rich, best quality, resembles Bergen's Yellow. Heavy bearer in our nurseries. Last of July. Freestone.

Glendale Beauty-In our nurseries this has proven well worthy of its name. Very large, yellow covered with red; flesh yellow, very juicy, delicious flavor; beautiful, productive. July.

Sloan's Carolina-A magnificent large yellow peach; best quality, juicy and rich, ripens after Crawford's Late; splendid for market or family use. Very productive with us.

Sallie Worrell-A celebrated new peach of N. C., said to be of largest size, finest quality; white flesh, red cheek, freestone. Has not fruited with us.

Langworthy-Medium, highly colored with red; white flesh, juicy, good quality; an immense bearer; freestone. Very desirable for its season. August.

Cooper's Mammoth-Very large, yellow, best quality; resembles Susquehannah. Last of July. 
Henkel-Originated by Judge Henkel, of Round Top, Fayette county, Texas. A seedling of Crawford's Early, of which it is an improvement. Very large, yellow flesh, juicy, delicious flavor; freestone.

\section{NEW PEACHES.}

Esther Doom-A very fine seedling;peach, found by Maj. Doom, of Austin; a very large yellow cling; ripens in August.

Lady Ingold-Resembles Early Crawford, and claimed by some growers to be superior to it.

Pallas (Seedling from Honey)-The fruit resembles the parent in size, but is more round in shape. Flesh white, melting, with a rich, vinous aroma, partaking in this of the flavor of the Grosse Mignonne.

Muir-A favored peach in California for canning and drying; a yellow freestone. Not fruited here yet.

Dwarf Japan Blood-Said to ripen with the Alexander; as large and ripens better.

Spottswood-Similar to Chinese Cling, but freestone, very large and of best quality. Middle of July.

Rosedale, September-Free, a first-class peach that originated here, as large as Crawford's; yellow flesh.

Cora-Above medium; white pale cheek; flesh white. Middle to end of September. An improvement on Lady Parham.

Robert-Rareripe strain. Large, creamy white and crimson cheek; flesh white, slightly veined with pink, juicy 'and vinos; quality best. Freestone. Middle of August.

Stonewall Jackson-Almost similar to Gen. Lee in size and quality, but a week later, and the tree a more compact grower; July 15 th to $25^{\text {th. }}$.

Sylphide-Similar to Chinese Cling, but maturing one month later.

Yellow Angust-Ripens here about the 2 oth of August; is a good peach; originated here. 
August Freestone-This is another seedling found in our nurseries that will be valuable.

\section{HAUPT'S SERIES OF SEEDLINGS.}

We are indebted to Mr. Haupt, of Kyle, Texas, the originator of that valuable peach, Alice Haupt, for twenty-four new varieties of excellent peaches, most of them being seedlings of the Chinese Cling, or rather descendants of the Chinese. Mr. Haupt writes that he cut the scions which he sent us from trees that were then fifteen years old, and still healthy and productive. All are very hardy and productive. They have fruited with us; are very strong growers, looking much more vigorous than old varities.

No. 14, Huapt's Extra, or Sucking Peach-As Mr. Haupt calls it, is a clingstone, of largest size, equal to Chinese, which it resembles. Very juicy, excellent quality; ripening last of July.

Haupt's August-Freestone; early August; large size, fine flavor, straw color with red cheek, white flesh, red next seed, firm, very juicy, rich, first quality, roundish oval; ripens early October. A most valuable late peach.

Haupt's October Freestone-Similar in quality and appearance to the October cling.

We have Mamie Ross, Pansy, Pabor, Burke, Japan Blood, Cora, Pallas and many others.

\section{ORNAMENTAL PEACHES.}

Double-flowering Peach Trees (Amigdalis Persica Flore Pleno)-These trees are extremely ornamental when in bloom, bearing abundance of very double flowers as large as camelias or roses, and some of them have very nice, sweet fruits as well.

Double White-Pure white and very double.

Double Pink, or Cameliæflora-Pink, fine.

Double Crimson-Dark crimson, very beautiful.

Versicolor-Flowers variously white and red or variegated on one tree.

Blood Leaved-Leaves blood red, fruit small; very ornamental. 


\section{NECTARINES}

will grow anywhere that the peach will, and require the same culture. The fruit, having a smooth skin, is liable to the attacks of the curculio.

Boston-Large, bright yellow with red cheek, flesh yellow, sweet and pleasant. Freestone.

Downton-Large, dark red cheek; rich and highly flavored.

Elruge-Medium, greenish yellow, red cheek, juicy and excellent.

Early Newington-Large, pale green, red cheek; a very juicy cling.

Hardwick's-Large, violet red cheek, juicy and rich.

Pitmaston Orange-Large, orange; flesh orange and juicy. One of the best.

New White-Large, pure white; flesh tender, juicy, 'vinous, very good; early, freestone.

Red Roman-Greenish, yellow and red; rich and good.

Stanwick-A very fine English sort.

\section{APRICOTS.}

This fine fruit succeeds well in many parts of Texas. The best varieties are as follows:

St. Ambroise-Large, juicy; one of the best.

Moorpark-Large size, red cheek, juicy, rich; one of the best.

Breda-A very large hardy; grows a bears where other sorts would fail.

Silva's Seedling-A California sort of great promise.

Peach-Very large, and perhaps the finest of all apricots.

Turkey-Medium, "juicy and pleasant; kernel as good as an almond. 
Royal-A very fine French sort; large, oval and vinous.

Early Golden (Dubois)-Small size, pale orange; flesh yellow, juicy, sweet and good; vigorous grower and productive.

Golden Drop-Bright orange; melting, with a delicious, fine flavor.

Large Early-A fine, large, early variety, of vigorous growth, one of the best of the early sort.

\section{PLUMS.}

The improved Chickasaw varieties do remarkably well all over Texas. They are more reliable than peaches, in fact they are almost certain to bear a good crop of fruit every year. Many of the finer kinds are of the best quality, and are very profitable for market. Foreign plums do but little good in Texas. Occasionally we find a few trees doing well, and bearing, but they are not to be recommended. Price List will be sent on request.

\section{IMPROVED CHICKASAW AND NATIVE VARIETIES.}

Eariy Red-Large, round, red, good quality, very prolific. Early May.

Caddo Chief-One of the earliest, ripens about the same time as Early Red. Medium size; firm, bright red.

Lone Star-Ripens a little later than Caddo Chief; large, nearly the size of Wild Goose; quality good, light red, prolific; very valuable.

Jenny Lucas-Large clear bright yellow, nearly the size of Wild Goose;' good flavor. Last of May.

$\bigvee$ Wild Goose-Very large, dark red, with white bloom; flesh yellow, fine, juicy and rich. Tree a vigorous grower and abundant bearer. It is a native of Tennessee, and undoubtedly the finest plum we have for Texas. Ripens last of June; will be of much better quality if ripened in the house; a good shipper.

Indian Chief-Large, round, deep red; very productive. July. 
Deep Creek-Said to be one of the best of our native plums. Medium to large, deep red, small seed; bears young; prólific.

Golden Beauty-Large, round, rich golden yellow, very firm; small seed. August.

De Caradeuc-Medium, round, skin yellow, with dull red cheek. Flesh juicy and highly flavored. June.

Hattie-Medium, round, bright red, very : sweet, and of good quality. Ripens after Wild Goose.

Newman-Medium, oblong, skin bright red, quality very good; tree a very prolific bearer. July. Ripens well in the house.

Miner (Townsend) -An improved variety of the Chickasaw; originated in Lancaster, Pá. Medium size; oblong, pointed apex; skin dark purplish red, slightly mottled, with fine bloom; flesh soft, juicy, vinous, adheres to the stone. July.

Harper-Large, round, deep red; delicious flavor.

Kanawha, or Peach-leaved-This is an excellent late native variety; it colors sometimes before it is ripe, but is not good before it ripens on the tree. Medium, round, skin bright red, quality very good; freestone; very productive. July to August.

Yosemite-Very strong grower. Very large leaves, quite distinct in growth and foliage from any other plum; seems to belong to Prunes Americana, or to be' a hybrid between that and some European sort. Has not fruited with us, but is said to be productive and a sure bearer; yellow. September.

Bingham-A handsome, large, deep yellow plum, dotted with red; juicy and rich; fair grower and productive; valuable. September; origin, Pensylvania.

The New Marianna Plum-This plum is said to be a seetling of the Wild Goose. It was introduced by Chas. N. Ely, of Chambers county, Texas, who tested it for twelve years. Good as a stock, is easy to grow from cuttings, but with us does not fruit.

Zelsey's Japan Plums-This remarkable plum was imported from Japan in $187 \mathrm{r}$, by the late John Kelsey, of Berkeley, California, whose name has been given to the fruit. It is highly recom- 
mended by all parties who have grown and fruited it, and we have no doubt but that it will succeed in Texas, as the Japan persimmon and other Japan fruits and trees grow and bear as well as our native varieties. Its wonderful productiveness is unsurpassed by any other plum, either native or foreign. It comes into bearing at the age of two or three years. The fruit is of the largest size, being from seven to nine inches in circumference, and specimens weighing six and a half ounces each; it has a small seed. It is of a rich yellow color, sometimes covered with bright red, with a lovely bloom. It is heart-shaped. Ripens about first of September. It is of excellent quality, rich, melting and juicy. It is said to excel all other plums for canning, and as a dried fruit, to surpass the best dried prunes.

\section{NEIV PLUMS.}

Hattonkin No. 1-H. H. Bergens Strain. Said to be the earliest of the Oriental plums, twice the size of Wild Goose. Fruit oval, yellow transparent in color.

Satsuma Blood-Vigorous grower; said to be one of the best Japan plums. Fruit large, delicious, flavor red flesh with mottled skin.

Yellow Japan-Very vigorous grower. Fruit said to be a beautiful yellow transparent color; almost globular in shape.

Burbank Japan Plum-Mr. Burbank, of Calafornia, says this is the best of all Japan plums. Fruit fire to five and a half inches in circumference, nearly globular; clear cherry red, with lilac bloom Flesh deep yellow; very sweet agreeable flavor.

Botan-Fine, large, purple, flesh yellow.

Ogon-Large, nearly round. Yellow.

Chovot-Large, greenish purle.

Prunus Pissardio-Very ornamental. Leave deep purple. Fruit bright crimson; very productive.

Simon's (Prunus Simoni, or Apricot Plum).-Tree of medium height, quite upright in habit, leaves long dark green. Fruit resembles a flattish smooth brick red tomato. Flesh fine, apricot yellow, firm, and with a peculiar aromatic flavor. 
Robinson-Of the Chickasaw family. Fruit medium; nearly round; red, prolific, little later than Wild Goose.

NUTE. - There is great confusion in the names of the Japan. plums. Some sorts are sent out under two or more names, and it. will be some time before we get them named correctly. P. J. Berchman and other reliable men are testing them, and we will soon prove them. We have on our grounds nearly all that promise: well, and can show them to visitors as they mature.

\section{FOREIGN PLUMS.}

We keep up a stock of the following kinds, which embrace thebest varieties:

Coe's Golden Drop--Large, oval, yellow, rich and sweet; a cling:

Donnison'Superb-Large, yellowish green, juicy, rich.

General Hand-Large, yellow, free, vigorous.

German Prune-Medium, oval, blue; juicy and rich.

Imperial Gage-Large, oval, greenish yellow; juicy and delicious.

Reine Claude de Bavay-Greenish streaked with red; rich and fine.

Shropshire Damson--Medium, dark purple. Fine for preserves.

Richland-Medium, reddish purple; juicy and sugary.

Damson-Small, blue, and good preserves.

We have Petit Prune, Bulgarian Prune, Hungarian Prune, French Prune and others.

\section{CHERRIES.}

Cherries are rather uncertain in Texas. Here they do but little good, and will not pay for planting; but from different localities of Northern and Western Texas, we have received good reports of them. We can furnish trees of several of the best kinds for this climate.

The Country Gentleman says: "Buy your trees of a nurseryman who has established his reputation." 


\section{JAPANESE PERSIMMONS.}

(DEOSPYROS KAKI.)

We have had this valuable fruit to bear with us three seasons, and we have been better pleased with it each year. We are fully convinced of its adaptability to Texas and the Southern States. The trees have grown vigorously, withstood all the vicissitudes of our climate and have borne a good crop of fruit each year. The tree is very ornamental, has large, luxuriant foliage, and in the fall, when loaded with its golden fruit, is worthy of a place in all ornamental grounds.

The tree is very hardy, needs only to be cultivated while young, until it gets established, it will then take care of itself, if the weeds are kept down; grass will not hurt it; it is a regular, upright grower, does not occupy much space and can therefore be planted in flower or vegetable gardens, or can be grown in an orchard with same treatment as the pear requires.

The fruit of most of the varieties is of very large size; globular or oblong in shape, of a rich yellow or vermillion color, sometimes an orange red. The globular shaped varieties resemble a large tomato. The flesh is soft, with a pleasant, sweet, slight apricot flavor, somewhat similar to our native persimmon, but richer and more delicate. The trees begin bearing very young and are enormously productive. The fruit can be kept a long time in the house and bear shipping well. It is best to gather the fruit before frost, if wanted to be kept long in the house, as it will not keep as well after being touched by frost. We have kept fruit in the house from September to February.

Among-Large, nearly globular, orange red; good quality; good keeper.

Mikado-Flat or tomato-shaped; rich orange yellow; best qualityCan be kept a long time. Fruit on young trees seedless; very pro lific.

Hagakume-Synonyms, Pound, Seedless, Menokaki, etc. Largest size; deep orange red; nearly always seedless; excellent quality; keeps late. 
Masu-Fruit of largest size; good quality.

Zeng:-Medium, nearly globular; flesh dark, best quality, and one of the best for dryng.

Kurokumo-Round, somewhat flattened at the stem, bright vermillion; large size.

Hachyeya-Synonyms, Yomato, Imperial; usually oblong. Very large; orange red; good quality; keeps late.

Goshonaki-Flat, or tomato-shaped; medium size; orange red; quality unsurpassed,

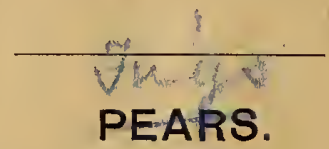

Brunswick, or Madonna-Very large, violet.

Black or Blue Ishia-Medium, blue, excellent.

Brown Turkey-Medium; brown, very sweet and prolific; hardy.

Celestial-Small, pale violet, with bloom; sweet; hardiest of all.

Green Ishia-Medium, green, crimson pulp; very good.

Jaune Hative-Medium, yellow, very rich. Early.

Lemon-Large, yellow, sweet, very good; next to Celestial in hardiness.

White Marseilles-Large, white, very good, hardy.

\section{QUINCES,}

Hourish in any good garden soil, which should be kept mellow and well enriched. Prune off all dead and surplus branches, and thin out the fruit if bearing too freely. Fruit is fine for cooking or preserving.

Apple or Orange-Large, roundish, color golden yellow; very productive. October.

Angers-Fruit large, a vigorous, strong grower. 


\section{MULBERRIES.}

Mulberries are becoming very popular, on account of their hardy, vigorous growth. They make beautiful shade trees, and the fruit is good for feeding hogs and poultry and for making tarts, etc.

New American Everbearing-A hardy, rapid-growing variety. Makes a large beautiful shade tree; and bears a delicious fruit for several months in the year. Very prolific.

Morus Alba (whITE)-A common variety, used for feeding silk worms.

Russian Mulberry-A valuable variety, introduced by the. Russian Mennonites. A rapid grower; fine for shade.

Italian Mulberry-(Monus Morettiana)-Fruit large and delicious; very prolific; also good for a shade tree.

Downing's Everbearing-Large, delicious fruit; good shade trees.

\section{POMEGRANATES.}

These make very pretty ofnamental shrubs or small trees, if pruned up, and the sweet varieties produce a most delicious fruit. They are very hardy, growing well, with but little attention. We have both, the sweet and the subacid, and four varieties of the double flowering.

\section{NUT BEARING TREES.}

\section{ALMONDS.}

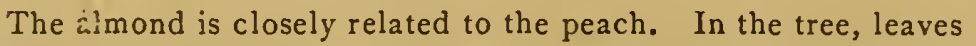
and flowers it resembles the peach very strongly; it is quite as hardy as the peach and requires the same general treatment.

Soft Shell, or Ladies Almond-One of the finest of all the almonds. Large, sweet; shell very thin; sold by confectioners.

Sultana-Soft shell, excellent quality; smaller than the above, but equally as good. 
Princess-Tender shell, sweet, one of the varieties usually sold by confectioners.

Hard Shell-Shell hard; kernel sweet; large and plump. Very hardy, will succeed, where the soft shell varieties do not bear.

Languedoc--This variety is planted extensively in California.

\section{CHESTNUTS.}

American Sweet (Castanea Americana)-The well known variety of the Southern States, does well with us. Makes a beautiful tree and bears well.

Italian, or Spanish (Castanea Macrocarpa Vesca)-Tree very handsome, round-headed. Fruit very large, valuable for fruit or ornament.

\section{WALNUTS.}

English Paper Shell, or Maderia Nut-This is the common English Walnut of commerce. "Very thin shelled, good flavor.

American Black Walnut-We keep good trees of this variety in stock. It is too well known to need describing.

Pecan Nuts-We grow these from selected seed. The trees are very hardy.

\section{SMALL FRUITS.}

STR.AWBERRIES.

The soil best suited to the strawberry is a deep, rich, sandy loam; but whatever kind of soil is used, deep culture is indispensable. Unless the soil is naturally very rich, it should be well manured, and ploughed or spaded deep and thoroughly pulverized before planting. Be careful not to expose the roots to the wind or sun in planting; do not plant deep, but press the soil firmly about the roots.

The distance for planting will depend on the object for which planted; there are a number of systems followed: If the largest 
fruit is desired, the hill culture is best; but if not too choice about the fruit, the matted row system is better. For hill culture, plant in rows about fifteen inches apart in the rows, and same distance between the rows, two or three rows to a bed; keep the runners clipped off. For the matted row system, plant in rows, one foot apart in row, and two and a half to three feet between the rows; let the runners grow; keep them well cultivated and clean. Mulch during summer.

A naturally moist soil is the best for the strawberry; on dry soil they often burn out during our hot summer. Pistillate varieties must have some perfect flowered sort planted near them. We furnish plants of several varieties best adapted to our climate.

\section{RASPBERRIES.}

Some varieties can be grown very profitably in Texas, and we can recommend the following as the best for here.

\section{BLACK CAPS.}

Doolittle (Am. IMPRoved)-Medium, black, £ood flavored, hardy, and very productive. A favorite market berry.

Mammoth Cluster-Very large, fine, productive, hardy. Introduced by A. M. Purdy, and growing in favor.

RED RASPBERRIES.

Philadelphia-Medium, round, dull red; mild flavor, hardy, and very productive.

Cuthbert (The Queen of The Market)-Large, conical; deep, rich crimson; firm; of excellent quality. A vigorous grower; hardiest of the red.

Brandywine-I - arge, bright red, very firm.

Reliance-A descendant of the Philadelphia. Fruit large, dark red, firm, rich, sprightly raspberry flavor; vigorous, productive.

\section{CURRANTS AND GOOSEBERRIES.}

It is money thrown away to buy these; they will not do here. Still, as every season people will insist on having them, I keep up 
a supply of the varieties that MAY succeed in some places. They require good nursing and mulching.

\section{BLACKBERRIES.}

These berries are a great success here-never do better anywhere.

Lawton-The well known market variety. Fruit large, productive. Late.

Zittatinny-Large, black, sweet; soft when black; very hardy . Late.

Wilton's Early-Large, sweet, fair flavored; very productive Ripens up the fruit together. Early.

Texas Improved-An enormous bearer; very hardy; does not rust and is not affected by our dry, hot summer. Fruit large, sweet and luscious. Early.

Texas Hybrid Pink-A remarkable berry of Texas origin. Fruit medium size; red or delicate pink when ripe. Flavor sweet but not insipid, nearly as good as strawberries for sugar and cream. Vine evergreen, and not affected by our dry, hot weather. Early.

Texas White-An upright, strong grower. Fruit pure white, small or medium, sweet.

White Dewberry - This is a trailing vine; very hardy Fruit a clear white, rather too sweet, but delicious with sugar and cream. Early May.

Black, or Common Dewberry-We have plants of the choicest kinds of these.

\section{GRAPES.}

Grape-growing is now becoming as important and profitable a feature as orchard raising, and as the fruit may be grown to perfection and abundance on vines planted six feet apart each way, there is nothing to prevent every farmer or lot owner from having a variety and plenty. Texas is second to no other State in the 
Union, except California, as a grape growing country. Grapes grow luxuriantly everywhere, in woodlands and cross-timbered prairie lands, in the poorest and in the richest soils, and we have only to look to the wild grapes to understand how well it will pay us to grow the finer garden sorts. Besides growing grapes for our private use and for shipping in the berry, there is a vast and promising future before us as a wine-making people.

For west and southwest Texas, those varieties belonging to Vitis Æstavalis are to be recommended, as they seem specially adapted to that section. For light soils we would recommend the Herbemont and for limy, black land the Lenoir, or Black Spanish. Wine making from these two kinds, especially the Herbemont, is already quite an industry in Austin, Colorado and adjoining counties. Price list will be sent on request.

Concord-Berries large, blue black; bunches large and showy. Strong grower and very productive. Good for market or wine. July.

Catawba-Bunches medium, berries large, red with lilac bloom; juicy, aromatic, sweet.

Delaware-Bunches small, compact, shouldered; berries smallish, round, light red; exceedingly sweet, sprightly and vinous. Ex. cellent. July.

Diana-Bunches large, compact; berries round, reddish lilac, and a fine eating grape.

Hartford Prolific-Bunches large, shouldered, compact; berries large, round, black. Last of June. A fine market fruit.

Isabella-An old standard sort, highly prized where it will thoroughly mature. Bunches long, large, loose; berries large, oval, sweet and musky; a good keeper. Does not mature well here.

Warren, or Herbemont (Estavalis) -Bunches large, shouldered, compact; berries medium, light blue, with bloom, sweet, vinous, delicious. The best wine grape for Texas; very vigorous and hardy. August.

Lenoir (Æstivalis)-Synonyms, Black Spanish, El Paso, Burgundy, Jacques, etc. Medium, black, no pulp, bunch large, long 
and compact, generally shouldered; colors sometimes before it is ripe. A good wine grape; does well on limy soils, where other grapes fail. Rot in some localities.

Black July (Æstrvalis)-Synonyms, Devereux, Lincoln, Sumpter, Thurmond, Sherry: Bunches medium, compact, berries small, black, sweet, vinous. A good wine grape. July.

Iona-Bunches large, shouldered; berries medium, clear red; flesh juicy, sweet and vinous; not very hardy. July.

Ive's Seedling-Bunches medium, compact; berries black, medium and roundish oval. One of the best wine grapes in the South. Last of July.

Perkins-Bunches medium to large; berries large, roundish, oval, rusty white; early, and a fine market variety. Early July.

Goethe-Bunches large, compact, shouldered; berries large, oval, yellowish green; tender, juicy and sweet. Does well with us. August.

Wilder-Bunch large, compact, shouldered; berries large, round, black, juicy, sweet and rich.

Lindley-Bunch medium, long; berries round, reddish; tender, juicy and sweet. No pulp; best quality. Early.

Agawam-Bunch large, shouldered; berries large, round, ma roon, tender, juicy, vinous. July.

Cornucopia-Bunch large, compact, shouldered; berries full medium, black, juicy, but not pulpy. July.

Brant-Bunch and berry medium, very juicy, sweet and, when well ripened, rich and aromatic. June.

Autuchon-Bunch long and shouldered; berries medium, greenish golden, sprightly and rich. July.

Alvey-Bunch large, long, shouldered; berries black, tender and vinous. A vigorous grower.

Elsiriburgh-Bunches large, loose, shouldered; berries small, black, very sweet and melting. Early. 
Merrimack-Bunch large, broad, compact; berries large, black, tender to the centre, juicy and sweet. August.

Scuppernong-One of the best known Southern grapes; bunches seldom composed of more than eight or ten berries, which are round, large and of a bronze color when fully ripe. Flesh thick, pulpy, very juicy and sweet. It is a slender and rampant grower, and covers a great surface in a few years. An excellent eating or wine grape.

Triumph-Bunch and berry very large; white or golden, when ripe. No pulp; excellent quality; equal to best foreign; very showy, productive and valuable. Late.

$\checkmark$ Prentiss-A pure native white grape. Bunch large, not often shouldered, compact. Berry medium to large, yellowish green, sometimes with a rosy tint on side next to sun; skin thin but very firm. Flesh tender, sweet, melting, juicy, with a very pleasant and musky aroma; free from foxiness, little if any pulp, seeds few and small; very similar to Rebecca in quality, but vine a vigorous grower, and foliage very distinct from Rebecca. Foliage healthy, thick, resembling Diana.

Duchess-Bunch medium to large, often eight inches long, handsomely shaped, shouldered, compact. Berry medium, round, of a greenısh white in color, and clings to the stalk with great tenacity; skin thin, translucent, and very firm; flesh tender, without pulp and in flavor will rank as best. Ripens between the Delaware and Concord.

Black Hamburgh-Bunches large, berries very large, black. One of the finest foreign grapes that for the last fourteen years we have grown and fruited satisfactorily in our nurseries.

Rose Chasselas-Bunches and berries medium, reddish, sweet and delicious. A foreign grape that ripens to perfection in our nurseries.

These two foreign grapes will succeed to perfection with care, but are more tender than our American grapes.

Niagara-One of the best white grapes we have.

Pocklington-A seedling from the Concord. Vine hardy, strong 
grower, light golden yellow, bunches large, sometimes shouldered. Berries very large, round and thickly set, and a very showy grape; juicy and sweet, with little pulp; but not first quality, until fully ripe. Ripens with Concord.

Elvira-A seedling of the Taylor. Bunches medium, shouldered, very compact. Berry medium, pale green with white bloom, sometimes tinged with red when fully ripe; skin very thin, nearly transparent, pulp sweet, very tender and juicy, fine flavor. Ripens about ten days after Concord. Makes a fine white wine.

Salem (Rogers No. 53)-This is one of the finest of Rogers' hybrids. Bunch full medium, compact and shouldered. Berry large, of a dark chestnut or Catawba color; sweet with rich aromatic flavor. Ripens about same time as Concord.

Perkins-Bunch medium to large, berries medium, pale lilac or reddish color, when fully ripe; with a thin white bloom, flesh pulpy, sweet and juicy, with a strong foxy flavor. Last of June.

\section{SELECT FOREIGN GRAPES.}

Black Burgundy-Bunches small, berries round; black; produces a claret wine of good quality.

Rose of Perd-Very large bunches; berries roundish, brownishblack, valuable for market, one of the best.

Sultana-Long, compact bunches, berries amber colored, seedless. Makes fine currants; also used for wine.

Zinfandel-Bunch very compact and shouldered; berries large, round, dark purple; heavy bloom; recommended as the best claret wine grape for California, and Mr. Munson, of Denison, Texas, says that it does best with him of any Vinefera that he has tried.

Black Hamburgh-The most popular and generally successful of all foreign grapes, bunches large, berries very large, purplish black, juicy, sugary and sweet.

Rose Chasselas-Bunches and berries medium, reddish, sweet and delicious. A foreign grape that bears and ripens to perfection in our nurseries. 


\section{ORNAMENTAL DEPARTMENT.}

No farm-house or town should be without a few flowers. Considering the age of Texas, our towns and cities are making as rapid strides in the way of having pretty little gardens as they are in commercial business. No home of any pretensions should lack a few shrubs or flowers; their very presence is the sign-board of civilization, and their absence the same of backwardness and ab. originality.

The Houston Post special edition has the following:

"Home! What a sweet sound, recalling the sweetest memories of our life, and associated with all that is dear to us. We should strive to make it as attractive as possible, and never begrudge anything spent in its behalf. Not only should we make it attractive within by catering to all the comforts desirable, but also think of its exterior, and adorn the surroundings with flowers and other suitable ornaments pleasing to the eye. Flowers are to the eye what music is to the ear, and both together, when properly cultivated, are sure signs of a higher order of civilization. * * * Let us beautify our homes, and we will be amply repaid by the soothing influence of flowers when returning home tired from our day's work."

That shrubs cannot be grown satisfactorily in Texas is a common opinion that we should repudiate, as we have a whole host of the finest flowering shrubs and evergreens, that are as much at home here as anywhere in the Union; indeed, we are more favored than overlooked in this respect.

We have spared neither exertion nor expense in bringing together a fine assortment of deciduous shrubs that yield flowers from January to December, as well as many fine evergreens-some valuable for their verdure, and others for their flowers. Specimens of everything in our catalogue may be seen in our nurseries. We have only retained what we have proven to be worthy of a place, and discarded that which we found inferior or would not do well.

Ornamental hedges are growing in favor every year. The California Privet makes a fine shelter from the cold weather, and is useful as a screen to hide unsightly objects. The other privets 
make good hedges. The Anonymous makes a pretty dwarf hedge or border for the garder -is healthy and evergreen-as does also the white-berried Pyracantha and Arbor Vitæs. The "Wild Peach" makes a dense and pretty hedge, as does likewise the Live Oak. The Cape Jasmine is used as a hedge plant in gardens at Houston, and a pretty one it makes, but it is not hardy enough for universal adoption. The Pomegranates may be effectively used in gardens, and will bear clipping admirably. Among deciduous shrubs, Deutzias, Forthythias, Altheas, Spiræas, and the Bridal Wreath, may be employed effectively, and, in addition to the purpose for which they are used, they well bloom freely.

\section{ORNAMENTAL AND SHADE TREES.}

American Chestnut (Castanea Americana)-Among all our nut bearing trees, there is none so valuable as the Sweet Chestnut. It is found growing naturally over a wide extent of country, and is perfectly hardy. It will grow on almost any dry soil, affording. valuable timber and delicious nuts. Makes a splendid shade tree.

Spanish Chestnut-Makes a beautiful shade tree, and grows well.

Catalpa-Very hardy, does well in the driest place, and with its large, glossy, heart-shaped leaves, and large cluster of white, tinged with purple, flowers, makes a beautiful shade tree for streets or walks.

Southern Cypress (Taxodium Distichum)-A beautiful, lofty tree, with elegant light green foliage.

Judas Tree-A very ornamental tree, covered with purple flowers before the leaves appear. We have two varieties-Cercis Canadenses, and C. Japonica.

Mulberry-The different varieties of the mulberry make thrifty and beautiful shade trees. The New American is especially to be recommended for light, sandy soils.

Mimosa (Acacia Julibrisson)-A most beautiful little tree, that forms a dense, broad head. In May or June it forms one sheet of pink flowers. 
Lombardy Poplar (Populus Fastigiata)-A well known tree, remarkable for its lofty, spire-like growth.

Sweet Gum (Liquidamber Styrciflua)-A native and beautiful pyramidal and very lofty tree. It is particularly pretty in spring, when unfolding its leaves, and again in the fall, when they change color.

Umbrella China (Melia Azedarach Umbraculifera) - A native of Lynchburg, Harris county, Texas, and now widely known over the State. In our nurseries we have the genuine kind, and we take great pains in preserving it true.

Sycamore (Plantanus Occidentalis) - A fast growing and good shade tree.

Tulip Tree (Liriodendron Tulipifera) - A beautiful and thrifty growing shade tree, with saddle shaped leaves and pretty flowers.

Live Oak (QUERCUS ILEX)-We have a good stock of these from one to ten feet high.

Flowering Peaches-Make very ornamental trees in early spring, and look quite singular when covered with their beautiful flowers.

As native trees are often called for, we keep an assortment of the following: Spanish and Common. Buckeye, Box Elder, Elms, Ash, Wild Chinas, Willows, Persimmons, Pecans, Black Walnuts, Youpon, Red Cedar, etc.

\section{Weeping Willow.}

Fountain Willow (Salix Americana Pendula, var. PUrpurea) -Of the many weeping willows we have tried, we find this the best for Texas. It grows rapidly and flourishes everywhere, and does equally well on its own. roots or worked on the native sort. Like the native willow, it will do best in a moist soil.

Basket Willow-This does well in moist soils.

Flowering Willow (CHILOPSIC)-Native of Texas; bears bellshaped purple flowers, all through summer. Small tree.

Maple, Silver Leaved-Makes a beautiful tree; very rapid growth. 


\section{ORNAMENTAL SHRUBS.}

Althæas (Hibiscus Syriacus)-These are pretty shrubs that grow well and bloom constantly from July till fall. We have a fine stock of pink, purple and pure white double sort.

Althea-Rubra Flora Pleno, (double red)

" Purpurea Flora Pleno, (double purple.)

" Alba Flora Plora Pleno, (double white.)

" Elegantissama-Double white, tinged with pink or purple; very hardy; profuse bloomer, covered with flowers during our dryest weather from July to Fall:

\section{New Varieties:}

Althea-Ardens.

" Alba Yleno.

" Boule de Feu.

" Purpurea variegata.

" Purpureus ruber plena.

"Speciosa spectabilis flora pleno.

"Totus Albus.

"Violaceus, also purpureaus flora plenissima.

Almond (Amigdolis) Double Rose Flowering (Pumela Rosea) -A beautiful small shrub, bearing in April, before the leaves appear. Small double rose-like flowers closely set all along the twigs.

Double White Flowering (Pumila AlBa)-Produces beautiful white flowers in April, similar otherwise to the Rosea.

Double-flowering Deutzia (D. Crenata, Fl. Pl.)--Free growing and highly ornamental, bearing clusters of white flowers shaded with pink. Blooms in summer.

Rough-leaved Doutzia (D. SCARA) - Will grow anywhere; bears an abundance of white flowers. Blooms in summer.

Slender Deutzia (D. GraciLis)-A pretty and easily grown shrub, with a profusion of pure white flowers. The plants commence blooming when not a foot high. Blooms in summer. 
Fortune's Deutzia (D. FortuneI)-Good grower and free bloomer; flowers very double and pure white. Blooms in summer.

Forsythima Viridissimz-A graceful Chinese shrub that bears a wealth of yellow blooms all along its branches in January and February. Nearly an evergreen; leaves assume a beautiful yellow and purple tint in the fall.

Forsythia Suspensa-A beautiful hardy shrub of weeping or pendulus habit; glossy deep green leaves and bright yellow flowers; blooms early, January and February.

Hydrangia Hortensis-A Chinese plant of great beauty, with large thick, deep green leaves and large globular heads of bloom of a white, pink or blush color, just according to the soil it is grown in. Must be kept in the shade; a capital house plant.

Lavender Shrub (Vitex Agnuscastus)-Known also as sage tree and chaste tree. Grows freely and produces bluish flowers all through the summer. Leaves and flowers very aromatic; blooms in summer.

Lilacs (Common and Persian Syringa)-With a little care this very desirable flower will do well. We offer strong grafted plants of the following choice varieties: Dr. Stockhart, Ambrose Verchafetta, Princess Maria, Syringa Vulgaris, Alba and purpurea, Syringa Persica Alba and purpurea.

Cydonia Japonica (JAPAN QUiNCE) - A beautiful shrub, growing well in Texas, and producing an abundance of scarlet flowers from February till May.

Crape Myrtles-(Lacerstramea.)

Lagerstramea, Indica Alba-Pure white, one of the most beautiful shrubs grown.

Lagerstramea, Indica Rosea-Rose or pink color, the variety generally grown.

Lagerstramea, Purpurea-Bright purple.

" Magenta-Color a bright Magenta.

"Indica, New Crimson-Color bright deep crimson, no variety heretofore introduced approaching it in color. A pro- 
fuse bloomer, blooms fist year after planting. The Crape Myrtle is one of our hardiest and most beautiful summer flowering plants.

Japan Judas Tree (Cercis JAPONICA)-An ornamental shrub, the branchlets of which are covered with dark red flowers before the leaves appear.

Judas Tree, American (Cercis Canadensis)-A beautiful small tree; covered with delicate purple flowers before the leaves appear. Leaves nearly round and of a very dark glossy green color; very ornamental, and in good deep soil makes a beautiful shade tree. A native of Texas.

Large-flowered Mock Orange, or Syringa (Philadelphuo Gran- DIFLORUS)-Very large white showy flowers. These plants grow well anywhere.

Slender-growing Mock Orange (P. Gracirs)-A most abundant bloomer.

Mexican Mock Orange (P. Mexicanus)-Grows freely, has darkcolored wood, and blooms profusely.

Columbian Mock Orange (P. Columbiana) -A new and beautiful sort; a good grower and fine bloomer. White.

Weiglia Rosea--Very beautiful and profuse blooming shrub that appreciates a little shade. Funnel shaped rosy flowers.

W. Amabilis, Splendens-A stronger grower than the preceding, and bearing larger leaves and flowers.

W. Desbois-A new and beautiful sort with dark red flowers.

Double-flowered Prune-leaved Spirea '(SpIRæa Pruni-Folia Fr. PL.) - Bridal Wreath of the northern and eastern States. Blooms before the leaves appear in spring, the stems being covered with little daisy-like flowers. Fine, hardy, and free growing; all the Spiræas are the same in this respect.

\section{6}

Spirea Nobleana-Foliage nearly red, very pretty; flowers in large panicles, pink; blooms all summer.

Panicled S. (S. Paniculita)-Blooms all summer, producing long panicles of pink flowers. 
Billard's S. (S. BILLARD1)-Blooms all summer, producing long spikes of sprayey pink flowers.

Dwarf S. (S. Callusa Alba)-A dwarf kind with white nowers, nearly ever blooming. .

Thunbergi Spirea-Habit dwarfish; fine feathery foliage. One of the earliest to bloom, being covered in very early spring with beautiful little white flowers. Good for borders or single shrubs.

Bridal Wreath (S. REvESI)-A good grower, producing iong arching branches that are completely covered with little clusters of white flowers in February and March. This is one of the most beautiful of garden shrubs and is quite at home in Texas. We have also the Double Bridal Wreath, which, if possible, is whiter and more beautiful than the single one.

This variety is known as the Bridal Wreath in Texas, while Prunifolia is known as the Bridal Wreath of the northern States.

Magnolia Purpurea (Purple Magnolia)-A deciduous variety from Japan with large showy and sweet scented flowers, the outside purple and the inside white, shading to purple. In our nurseries it blooms four times a year; first, before the leaves appear in early March, and afterwards at different intervals, depending on the rains. It is a shrub; begins to bloom very young, usually first or second year after planting; grows well here; hardy; needs no protection.

\section{DOUBLE FLOIVERING POMEGRANATES.}

Punica Alba Flora Pleno-Double white.

"Rubra Flora Pleno-Double red.

" Legrellias Pleno-Reddish yellow borders with white, very double; splendid; sometimes variegated.

Punica, Nana improved-Blooms freely, while young, and when large, plants are sheets of bloom; very profuse bloomer. Color rich, brilliant orange-scarlet.

These are all very hardy, beautiful shrubs.

Des Modium Penduliflorum-A Japanese shrub, with drooping branches covered with a profusion of pea shaped flowers during 
the summer and fall. We have both, the purple and white; stems usually die down in winter, but a new growth is formed in the spring.

\section{CLIMBING VINES.}

Japan Trumpet Vine (Bignonia Grandiflora)-Very showy, large orange flowers.

Tweedie's Trumpet Vine (B. TweEdInNA)-A fine climber from Buenos Ayres, with golden yellow flowers.

Star Jasmines (JASMinum) - We have the white and the yellow; both are nearly evergreen and free bloomers, and may be grown as dwarf climbers or garden shrubs.

Catalonian Jasmine (J. Grandiflora)-An evergreen climber with very sweet-scented white flowers.

Golden-netted Foneysuckio (Lonicera Brachypoda v. AureoRETICULATA-A thrifty plant with green leaves, beautifully netted all over with golden yellow veins. Leaves and stem change to bright crimson in fall.

Belgian Honeysuckle (L. Belicum)-Flowers pink, sweet and profuse; a good grower.

Scarlet Trumpet Honeysuckle (L. Coccinca BrowniI).

Yollow Trumpet Honeysuckle (L. Grata).

Japan Honeysuckle (L. JAPONICA) - Evergreen, yellow and white.

Chinese Eoneysuckle (S. Sinensis)-Evergreen, white, fragrant.

New Japanese Honeysuckle (Halliana or Splendida)-A new evergreen variety, flowers white, changing to straw color, very fragrant, and blooms from early summer till late fall.

Poriwinkle (ViNCa MAJOR)-Evergreen, and a fine trailer for growing underneath shade trees, in suspended baskets or window boxes, or for trailing on a trellis. Flowers large and purple.

Wistaria Sinensis v. Purpurea-A beautiful, rapid and longlived climber, producing in early spring large clusters of bluishpurple pea-shaped flowers. 
W. Frutoscens Magnifica-Like the preceding in habit of growth, and grows later. The flowers are a pale blue, borne in long tassels, and are sweet-scented.

Wisteria Sinensis Alba-Similar to above, but flowers are white; a most beautiful climber.

English Ivy-A beautiful vine with dark green leaves, that climbs over brick, stone or wooden walls or chimneys without alıy support. A hardy evergreen.

\section{EVERGREENS.}

Spice Laurel (Lauris Nobilis)-Sometimes called Bay Laurel; leaves have a spicy fragrance. A pretty bush, sometimes attaining the proportions of a small tree.

Cherry, or English Laurel (Cerasus Laurocerasus)-A largeleaved evergreen; very fine.

Chinese Tea Plant (Thea Bohea, or Viridis)-A beautiful, evergreen shrub, that produces large white flowers from September till frost. One of the finest for Texas.

Common Box (Boxus Sempervirens)-The common tree Pox; evergreen, and nice for gardens.

Silver-leaved Box (B. S. ARgenteA) - A beautiful variety of the former, the leaves being edged with silvery white.

Gold-leaved Boz (B. S. Aurea)-Like the preceding, but the leaves are edged vith golden yellow.

Sweet Myrtle (Myrtus Communis) - A beautiful evergreen with spicy-scented leaves and round, ball-like flowers. In the garden or as a window plant, it is very desirable.

Europear Olive (Olea Europea)-Admirable evergreen with pretty flowers.

Fragrant Olive (O. FraGRANS) - A beautiful little shrub, very sweet-scented; hardy; flowers after every rain during the sumıner and fall. Very desirable.

Fittosporum Tobira-One of the finest evergreens. It bears a wealth of bloom in spring, grows densely, and may be pruned into any shape. 
Common Privet (Ligustrun Vulgare)-Fine as a shrub and excellent as a garden plant, or best for hedge; bluish green in winter.

Neparl Privet (L. Nepcelensis) - Dwarf, with panicles of white flowers.

Californian Privet (L. Californiacum)-An erect and quick grower; good for screens or hedges.

Japan Privet (L. JAPONICUM)-A fine, thick-leaved variety, that makes a nice tree, hedge or screen.

Amoor River Privet (L. Amurense) - One of the finest privets, either for hedges or shrubs; it has blooms nearly equal to Persian Lilacs.

Cerasus Caroliniana-The "Wild Peach." A beautiful evergreen.

Japan Spindle Tree--(Euonymus JaPonicus) A beautiful evergreen, useful as a shrub, a trimmed bush, or for a garden hedge. Does first-rate in Texas.

Silver-leaved Spindle Tree--Variegated with white, and valuable for flower, gardens.

Large-leaved Spindle Tree.

Threo colored leaved Spindle Treo-A very beautiful variety; new sort.

Viburnum Odoratissimum-One of the finest evergreens, growing freely and blooming profusely, but is rather tender for Northern Texas.

Grand Duke Jassamine-Thick green leaves and very sweetscented flowers. With a little protection in winter this shrub will thrive anywhere in Texas.

Banana Shrub (Magnolia Fuscata) - A very fine evergreen shrub, bearing a wealth of small flowers of exquisite fragrance, one bud being sufficient to scent a room. Does well here.

Magnolia Grandiflora-Large shining leaves and sweetly scented white flowers. Well known all over the South; grandest of our Southern trees.

Oleanders (Nerium)--We have a fine stock of the White, Pink and Crimson single and double varieties. 
Nattam Plant (Nandina DonestiCa) - A desirable Chinese evergreen with fern-like leaves and terminable panicles of whitish flowers. Does well here.

Loquat, or Japanese Medlar (Eriobotrya Japonica)-A native of Japan and Southern China, and coes well here, especially in Southern Texas. The leaves are large, oblong, bright green above and downy beneath. It blooms in spikes at the end of the branches, in October and November, and ripens its fruit in the following spring. The fruits are orange colored, oval, as large as small apples, and are known in our markets as Japan plums. The fruit is frequently killed here by frost. Tree hardy.

Heath-leaved Cypress (Cupressus Ericoides)-Compact growing, very distinct, turns purplish in winter; very hardy and desirable.

Funeral Cypress (C. Funibris) - A fine growing and handsome little tree, with weeping branches.

Pyramidal Cypress (C. Sempervirens Prramidalis) - This is a most beautiful evergreen, growing quite erect and shaft-like. Fine for cemeteries, and does well in Texas.

Horizontal Cypress (C. S. Horizontalis) - As fine in every respect as the former, but instead of being shaft-like, it branches widely; pyramidal.

Irish Juniper (Junieperus Hibernica) - Upright in habit; beautiful; too far south for it to do well.

Scaly-leaved Juniper (J. Squamata) - A prostrate or spreading kind, hardy and ornamental. Desirable for planting on graves.

Tamarix-leaved Juniper (J. TAMARISCIFolia) - A slender-growing sort that does well here.

Sabine-leaved Juniper (J. Sabina) - A low trailing pretty tree.

Juniperus Stricta-Resembles the Irish Juniper in growth, but does better here, and foliage is a richer green.

Chinese Arbor Vitæ (Biota Orientalis)-Well known. It bears our drouths with impunity, and grows flourishingly where other things will fail.

Golden Arbor Vitæ (B. O. Aurea) - One of, if not the very finest evergreens, for Texas, we possess. It is so compact and pretty, 
growing thriftily and succeeding everywhere, and in the dryest weather.

Rollisson's Golden Arbor Vitæ-A fine colored and compact variety of the preceding.

Retinospora Squarosa (Japanese Cypress)-A dense-growing shrub, very pretty and desirable for gardens. One of the most satisfactory for drouthy lands.

Rosedale Hybrids-These are beautiful evergreens that originated in our nurseries. They seem to be hybrids between the Golden Arbor Vitæ (BIoTA Aurea) and Retinospora Squarosa, bearing a striking resemblance to both; are of very compact growth, of a sugar-loaf shape like Biota Aurea; and yet have a fine cedar.like foliage, resembling Retinospora Squarosa; are perfectly hardy, of a vigorous growth; altogether making a beautiful and valuable addition to our list of hardy evergreens.

Golden Arbor Vitæ Seedlings-These are seedlings from Biota Aurea, and are of more compact growth than the Chinese, but not so dense as the Golden. Very hardy and vigorous.

Gardenia Florida-Cape Jasmine. Foliage large and glossy. Flowers large, double, and very fragrant. Well known.

Gardenia Cameliaflora-Very large flowers. Larger than above. Gardenia Forturrii-Narrow leaved flowers, very large and regular.

Cunninghansis Sinesses-Chinese Pine. A very beautiful tree with shaped leaves, bright green above and white on the underside, horizontal branches. Does well here.

Cedrus Atlantica-An upright grower, pyramidal form, resem. bling Cedrus Lebanis; makes a beautiful tree, and does well here.

Cedrus Deodora-A very handsome and graceful tree, branching broadly at the ground, and gradually assuming a pyramidal form.

Retinospora Evicoides (JAPANese CyPREss) - A very desirable evergreen, somewhat like the Squarosa, but of lighter color.

Abelia Rupestris-A small shrub, with numerous pale pink tubular flowers, leaves small, of a very dark, glossy, green color.

Arbor Vitæ Pyramidalis-A beautiful variety of erect form, compact, dark green foliage. 
Pyracantha (Chategus PrRaCantha) - Without doubt the best for live fencing in the South. It grows rapidly, even in ordinary soil; bears clipping admirably, is easily managed, makes a perfectly impenetrable fence, and withal-with its dark green foliage, contrasting in the summer with its modest white flowers, and in the winter with a profusion of flame-colored berries-is extremely beautiful. We have also the evergreen.

White Berried Pyracantha-Which is more dwarf, hardier and more compact than the other.

\section{ROSES.}

We are now growing roses on a much larger scale than ever before, having annually added to our collection. We have many hundreds of the best varieties, all on their own roots; no budded or grafted plants are sent out unless specially ordered. The plants that we offer for sale are not small, pot-grown, like those usually received by mail, but are all strong, well-rooted, oút-door grown plants.

A deep soil well fertilized with stable manure is the most favorable to the Rose. In planting, select two or three of the strongest branches, cut these back to two or three inches each, and remove all the smaller ones. Each new shoot will produce finer flowers than if the old wood is left. After the first killing frost, prune back the bushes to three or four inches above the old wood. Repeat this annually, and a regular crop of fine flowers will be secured. Avoid crowding the bushes with numberless small branches. No good flowers must be expected unless the plants are annually pruned. Climbing or rampant growing Roses should not be so closely pruned as stubby growers. Send for price list.

\section{HYBRID PERPETUAL ROSES.}

These roses are robust, vigorous, very hardy, and well adapted to our Texas climate. The blooms are the largest, most double and prettiest of Roses, and embrace every color between pure white and the blackest crimson. Our beautifui velvet roses belong to this class. They bloom freely in spring and early summer, and 
if cut back a little, say toward the end of May; they will bloom again from the time of our August rains till frost.

Alice Dureau-A beautiful new blush rose.

Baronne Adolph de Rothschild-Brilliant, fiery crimson, perfect in shape, and exceedingly beautiful.

Baronno Prevost-Bright rose, very large; a noble old favorite.

Baronne Rothschild-Brilliant, crimson scarlet; fine.

Blanche Vibert-Pure white; a good grower.

Camille Bernardin-Vivid red, large and fine.

Cardinal Patrizzi-Dark velvety crimson; very beautiful.

Caroline de Sansal-Delicate flesh color, becoming blush, a magnificent rose.

Coronation-Beautiful pale rose, shaded with carmine and rosy pink, large and very double.

Compte Alphonse de Serenye-Clear red, large and full.

Dr. Hurta-A fine new deep pink rose; very large and full.

Coquette des Blanches--Pure white, large and finely formed.

Empereur do Maroc-Dark velvety red, shaded with purple.

Fanny Petzold-Pink changing to white.

Geant des Battailes-The most popular rose in this class; brilliant scarlet crimson; fine.

General Jacqueminet-Large, velvety crimson flowers; bloom in clusters; a luxuriant grower and first-class rose.

General Simpson-Bright carmine; fine form and free bloomer.

Genie de Chataubriant-Dark crimson, shaded with purple; very large and fine; a profuse bloomer.

Jean Gonjou-Deep rose, full and fine form.

I'Enfant du Mont Carmel-Deep purplish red, very large and full.

La Lisette de Beranger-Carnation rose color with white center.

Ia Phocine-Crimson scarlet; superb.

La Reine-Deep rosy lilac; very large, full, double and sweet; superb.

Mad. Alice Dureau-Clear rose, fine, large and double. 
Mad. Chas. Wood--Crimson shaded with purple; very large and double.

Mad. Ernest Dreol-Pale rose shaded with purple; long, full, fine.

Mad. Fremeon-Brilliant rosy carmine; very beautiful and a profuse bloomer.

Mad، Trotter-Dark red, large, full and vigorous.

Mad. Laffay-Large and fine, rosy crimson.

Ia France-An extremely large flowered pinkish lilac rose; very fine.

M'lle Amolia Halpin-Rosy pink; superb.

Marechal Souchet-Rosy carmine; large and beautiful.

Marechal Vaillant-Bright scarlet; very large and double.

Mario Louise de Vitry-Deep pink, very large; superb.

Mad. Girard-Fine globular form; large, very double and fragrant; deep rosy pink.

M'lle Jeanie Marix-A beautiful deep rose color.

Pæunia-Violet purplish, large and very durable; a fine old rose.

Paul Verdier-Bright intense rose; full and perfect.

Pier ro Notting-Blackish red, very good and full; excellent.

Port?and Blanche-Pure white; a good grower.

Prince Camille de Rohan-A magnificent blackish-red velvety rose.

Reire du Medi-A large, beautifully cupped and very beautiful pink rose.

Reynold's Hole-Bright red; vigorous.

Napoleon the Third.

Souvenir de la Reine d'Angleterre-Deep red; beautiful.

Triomphe de l'Exposition-Rich deep shaded with crimson; blooms in clusters; vigorous and one of the best.

Triomphe des Beaux Arts-Crimson lilac; very fine.

Sydonia-Delicate pink, very large double; a fine fall bloomer.

Souvenir de ma Coour-Deep rose; very beautiful. 
Yolande d'Aragon-Delicate pink; very large and full; a profuse bloomer.

EVER•BLOOMING-TEA-SCENTED ROSES.

These are, perhaps, the most favored Roses in Texas, on account of their continuity of blooming, fragrance, thrifty growth and adaptability to our climate. Many of the kinds have full and perfect flowers, and all are exquisite in bud. In color they comprise every shade, from the purest white to deep red, and from white to every shade of buff, salmon and yellow.

Bon Saline-Bright red, beautiful in bud, and a valuable late blooming sort.

Gerard Deboise-Bright red, large and full; a very profuse bloomer; one of the very best teas for Texas.

Homer-Rosy pink shaded with salmon; a fine rose and free bloomer; superb.

Duchess de Brabant-Rosy blush; large and fine. lent.

Comtesse Onvaroff-Shaded pink, large and fine blooms; excel-

Lady Warrender-Pure white, creamy center; extra fine.

Reine Marie Henrietta-Large, full and well formed, color cerise red; climber.

Adam-Flesh, centre salmon and fawn; large and beautiful.

Mad. Marie Van Houtte-White, "tinged with yellow; large, full, well formed.

Marie Guillot-A magnificent white rose; very large and double beautiful in bud or full bloom.

Perl des Jardens-Deep canary yellow; very large, equal to M. Niel.

Perl de Lyon-Deep yellow; large, double, free bloomer and vigorous climber.

La Pactole-Pale sulphur yellow; large, full and double.

Madame Damazin-Pale yellow tinged with pink, large and double.

Madame Louville-Bright pink, large and full; vigorous and fine.

Madamo Maurin-Creamy yellow; large, full and of fine form. 
Marechal Niel-Decidedly the finest yellow rose in existence; a vigorous grower and abundant bloomer.

Madame M Willeamoz-Creamy white shaded with salmon; superb.

Madame Trifle-Yellow suffused with salmon; large and double.

Madame Caroline Kuster--Pale orange-yellow, free bloomer; an extra good rose.

Catherine Mermet--Bright flesh color, large, full, beautiful form; fine bloomer.

Cornelia Cook-Pure waxy-white, large and perfect buds.

Coquette de Lyon-Canary yellow; pretty buds; free bloomer.

Climbing Devoniensie - Of climbing habit; flowers large; creamy white.

Etoile de Lyon-Chrome yellow; very double and full; deliciously fragrant.

General Tartas-Rosy-carmine, shaded purple, free bloomer.

Isabella Sprunt-Light sulphur-yellow, profuse bloomer.

Jean d'Arc-Fine citron yellow, very double, highly scented. Fine.

Louis Richards-Coppery-rose, center deep rose; large and full; fine form.

Mad. Camille--Large double; light aurora rose.

Mad. Falcot--Deep saffron yellow.

Mad. Magotton-A great favorite; very double; dark citron yellow, bright red center.

Mons. Furtado-Bright sulphur; full form, fragrant buds.

Niphitos-Purest snowy-white, long, well formed buds; very sweet-scerited.

Perl de Lyon-Flowers deep yellow, changing to apricots.

Safrano-Saffron and apricot; very fine in bud.

\section{NOISETTE ROSES.}

A fine, vigorous and free blooming race, raised from a cross betwen the Old Musk Rose and the China Rose, and further im. proved by interbreeding with the Tea-scented roses. Many of them 
are sweet-scented, fine climbers, and bloom in clusters during the summer and fall.

Caroline Marneisse-White tinged with pink; douple and perfect; a profuse and constant bloomer.

Celine Forestier-Bright yellow; good grower, profuse bloomer.

Lamarque-A magnificent rose; very large and double flowers of a white tinged with lemon-yellow color. Climber.

Cloth of Gold. or Cromatella-This is a Tea-Noisette, over thirty years in cultivation, and even now is one of the finest yellow roses in existence. It is a brilliant yellow color, globular in form and vigorous and free blooming in habit.

Woodland Margaret-Pure white, sweet-scented; blooms constantly in large clusters.

Solfaterre-Sulphur yellow; large and full.

Fellenburg-Small, rosy crimson; flowers in immense clusters; very free bloomer.

CHINESE AND BENGAL ROSES.

These are dwarf growers, blooming freely and constantly throughout the summer and autumn, making fine plants for pot culture, and for bedding out in the flower garden.

Agrippina-Rich, velvety crimson.

Pinls Daily-Bright rose; profuse and constant bloomer.

Granval-Bright red; very double.

Louis Philippe-Rich dark crimson; very constant bloomer.

Queen of Lombardy-Bright rosy red, free bloomer.

Sanguinea-Deep crimson; good grower, constant bloomer.

Triumphars-Rosy red; blooms profusely; full double; excellent. Madame Plantier-This is a hybrid China rose of great beauty, with large, pure white and very double flowers. It is a thrifty. grower and profuse summer bloomer.

Ducher-Pure white, fuil and fine form.

James Sprunt (Climbing Agrippina)-Deep cherry red; medium size, full and double; very fragrant, good climber.

Picayune-Small flowers, very double, deep pink, very constant bloomer; a lovely and desirable miniature rose.

Lorentia Rose-Fairy rose; a very small, neat rose, about the size of a ten-cent piece.

BOURBON ROSES.

These are continual bloomers, of vigorous, rapid growth, with rich luxuriant foliage. 
Hermosa-Light blush or flesh color; large, full and double. grows freely and blooms profusely; fine.

Sir J. Paxton-Deep rose, shaded with crimson; very strong grower, fine rich foliage, and free bloomer.

Souvenir de la Malmaison-Pale flesh with fawn shade; very large, full and beautiful. One of finest and best roses. Best of Bourbon.

Monsieur Jard-Clear cherry red; large and full.

Mrs. Bosanquet-Pale flesh color; large, double, perfect form; beautiful.

Imperatrice Josephine-Delicate pink; a fine rose, blooming in clusters.

Climbing Eermosa-In every way like the old Hermosa, but is a vigorous climber, with the free blooming habit of all Bourbon roses.

Appoline-Reddish pink; free bloomer, fine pillar rose.

Rev. H. Dombrane-Large, full, pale crimson.

\section{MOSS ROSES.}

Alice Leroy-Pale lilac; large and vigorous.

Beranger-Fine, light rose color.

Countess of Murinais-Pure white; vigorous; fine rose.

Crested (CRISTATA)-Very distinct; buds exquisitely fine.

Glory of Moses-Pale rose; very large, full and beautiful.

Laneii-Rosy crimson, shaded with purple; superb.

Luxembourg-Large, cupped, brilliant red, luxuriant.

Malvina-Deep pink; blooms in clusters.

Mad. de la Rochambert-Dark red; large and full.

Marie de Blois-Clear satiny lilac; large and fine.

Princess Adelaide-Fine reddish blush; large and vigorous.

Zebrina Moss.

\section{PERPETUAL MOSS ROSES.}

Alfred de Dalmas-Blush, with rosy center; blooms freely. Gen. Drouot-Deep purple; profuse bloomer; dwarf habit. Salet-Bright rose color; good grower; great bloomer.

\section{CLIMBING ROSES.}

These, for their hardiness and profusion of flowers, recommend themselves to all lovers of the beautiful. They are admirably adapted to cover arbors, walls, and any unsightly objects, and are almost ornamental in every situation.

Anna Maria - Blush pink, well formed and fine.

Baltimore Bello-Pale blush, nearly white; one of best climbers. 
Reauty, or Queen of the Prairie-Bright rosy red, large and cupped; A splendid grower.

Climbing Moss-Rosy crimson.

Mrs. Hovey-White shaded rose.

Perpetual Pink-Deep pink; blooms in clusters.

Pride of Washington-Dark rose; very double; large clusters.

Grevillier, Seven Sisters-Crimson, changing all shades to white; large clusters.

Dundee Rambler-White.

Champney-A fine pillar rose, quite double and very fragrant; deep' rose changing to pale rose.

Russells (COTTAGE)-Dark velvety crimson, very double and full; a profuse bloomer.

Lamarque (See Noisette.)

Madam Alfred Carriere-White with salmon at base of petals, large and full.

Fermosa (See Bourbon.)

James Sprunt, or Climbing Agrippina (See China and Bengal.) BANKSIA ROSE.

Double White Banksian-This favorite is known as the Lady Banks Rose and the Bridal Rose. It has fine, glossy green leaves on arching shoots, which are covered in spring with clusters of very double small white roses. When in bloom, the bushes seem mantled with snow, and when out of bloom they are as ornamental as evergreens. They endure our drouths with apparent impunity. A beautiful climber. Very strong grower.

Fortune's Double Yellow Banksia-Resembles the above in growth and foliage, but flowers are yellow in small clusters.

$$
\text { MICROPHYLLA ROSE. }
$$

Microphylla Alba-Pure white, very sweet; plants require age before they bloom freely; climber; good for hedging.

Microphylla Rubra (BURR ROSE)--Curious buds; a strong grower and good bloomer; blush.

Microphylla Rugosa-Deep rose, full and double; blush.

IOLYANTHA ROSES.

Mignonette-This is one of the most lovely and beautiful miniature roses imaginable; flowers full, regular, perfectly double and deliciously perfumed. Clear pink, changing to white tinged with pale rose, very hardy, constant bloomer.

M'lle Cecile Brauer-Flowers larger than the above, full, regular, perfectly double, rosy pink on rich creamy white; very fragrant. 



\section{LARMOUR \& WATSON,}

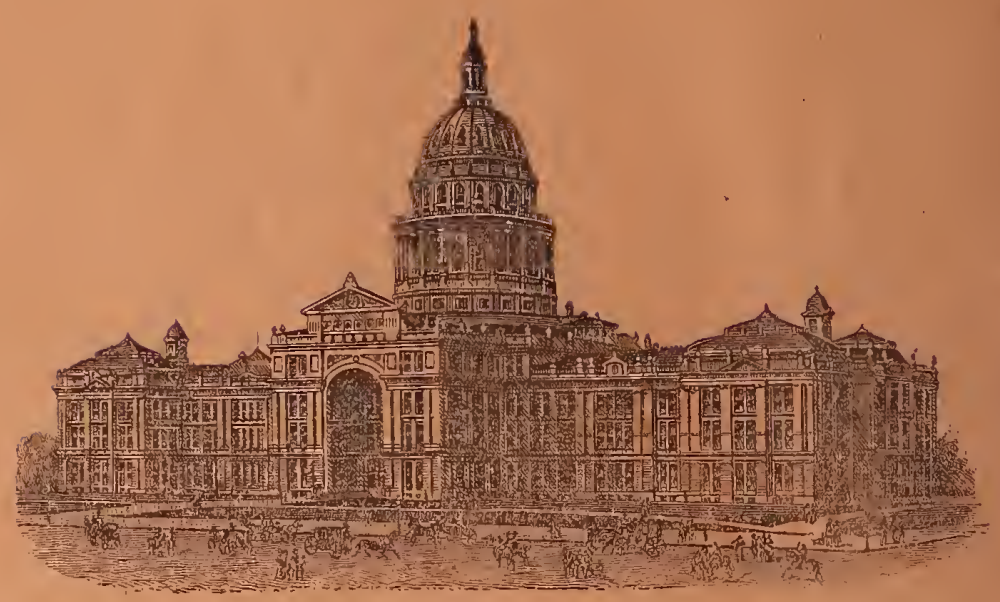

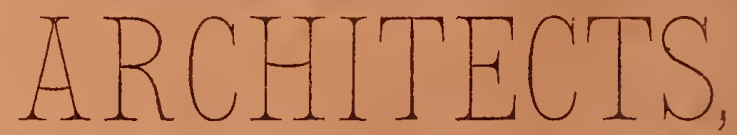

Room 5, Brueggerhoff Building,

$\begin{array}{llll}\text { AUSTIN } & \therefore & \therefore & \therefore\end{array}$

Correspondence Respectfully Solicited. 